\title{
Working
}

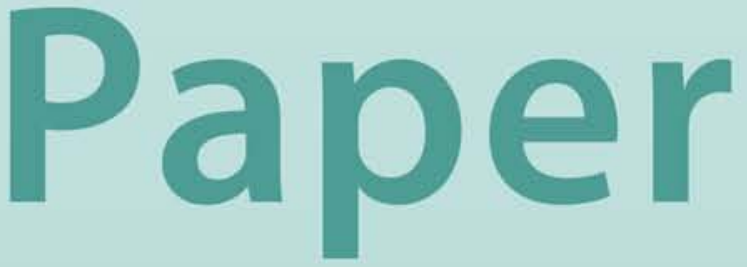




\title{
Bank Lending in Turkey: Effects of Monetary and Fiscal Policies
}

\author{
Burcu Aydın and Deniz Igan
}




\title{
IMF Working Paper
}

IMF Institute and Research Department

\section{Bank Lending in Turkey: Effects of Monetary and Fiscal Policies}

\section{Prepared by Burcu Aydin and Deniz Igan ${ }^{1}$}

Authorized for distribution by Stijn Claessens

October 2010

\begin{abstract}
This Working Paper should not be reported as representing the views of the IMF. The views expressed in this Working Paper are those of the author(s) and do not necessarily represent those of the IMF or IMF policy. Working Papers describe research in progress by the author(s) and are published to elicit comments and to further debate.
\end{abstract}

The period following the 2000-01 crisis was marked by a successful disinflation program sustained through inflation targeting and fiscal discipline in Turkey. This paper studies the impact of monetary and fiscal policies on credit growth during this period. Using quarterly bank-level data covering 2002-08, we find evidence that liquidity-constrained banks have sharper decline in lending during contractionary monetary policies and that crowding-out effect disappears more for banks with a retail-banking focus when fiscal policies are prudent. The results are statistically weak, suggesting that bank lending channel is not strong in Turkey and government finances has limited direct impact on credit.

JEL Classification Numbers:G21, E44.

Keywords: Bank credit, monetary policy, fiscal policy, panel data.

Author’s E-Mail Address:baydin@imf.org,digan@imf.org

\footnotetext{
${ }^{\dagger}$ We would like to thank Koray Alper, Eugenio Cerutti, Stijn Claessens, Enrica Detragiache, Davide Lombardo, Amine Mati, Rachel van Elkan, and seminar participants at the Central Bank of Turkey and 2010 SSEM Meetings for useful comments and suggestions. All remaining errors are our own.
} 


\section{Table of Contents}

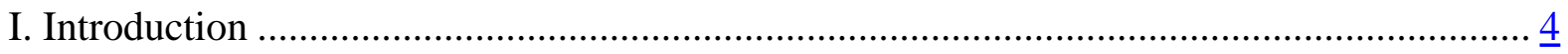

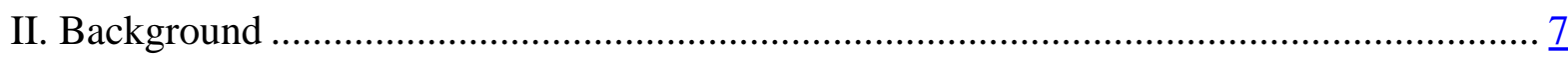

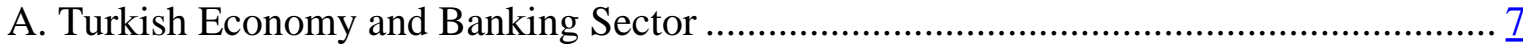

B. Related Literature .................................................................................................... 14

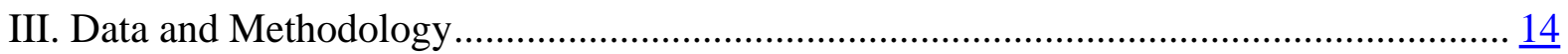

A. Data

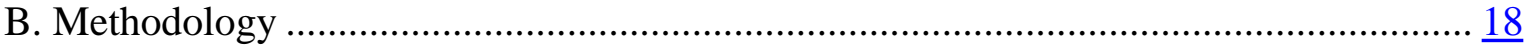

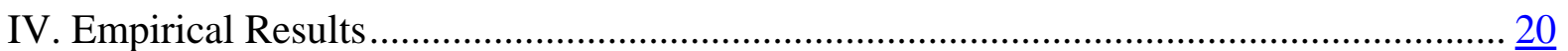

A. Baseline Results ........................................................................................... 20

B. Impact of Monetary and Fiscal Policies on Credit Supply: Currency Denomination of

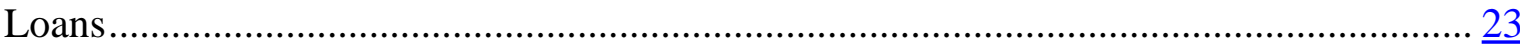

C. Impact of Monetary and Fiscal Policies on Credit Supply: Maturity of Loans ............. 24

D. Impact of Monetary and Fiscal Policies on Credit Supply: Bank Ownership ................ 26

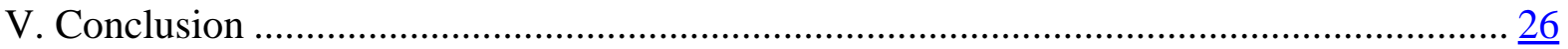

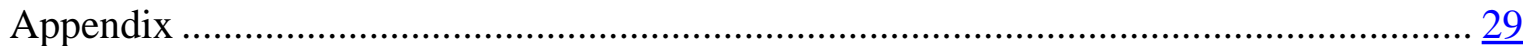

A. Definition of Variables........................................................................................... 29

B. Quarterly Smoothing of Fiscal Policy Variables..................................................... $\frac{29}{21}$

C. Coefficient Estimates from Step-1 Regressions............................................................... 31

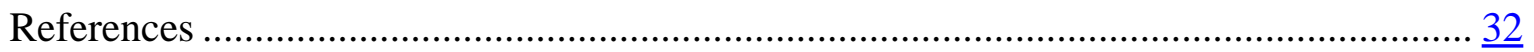




\section{List of Figures}

Figure 1. Inflation and Growth Dynamics, 1964-2008 ...................................................... $\mathbb{Z}$

Figure 2. Government Debt Financing by Banks ................................................................ $\frac{8}{8}$

Figure 3. Bank Credit to the Private Sector and Crises ............................................................

Figure 4. Restructuring of the Banking System Capital Adequacy ………………………...... $\frac{13}{30}$

Figure 5. Observed and Quarterly-Smoothed Fiscal Variables ............................................... $\underline{30}$

\section{List of Tables}

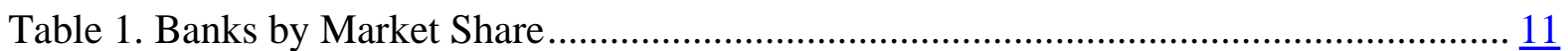

Table 2. Banks in the Sample ........................................................................................ $\frac{12}{12}$

Table 3. Summary Statistics ...................................................................................

Table 4. Summary Statistics of Major Balance Sheet Items................................................... $\frac{18}{22}$

Table 5. Sum of Coefficients on Monetary and Fiscal Policy Indicators ................................ 22

Table 6. Sum of Coefficients on Monetary and Fiscal Policy Indicators with respect to

Currency Decomposition of Credit....................................................................................... 25

Table 7. Sum of Coefficients on Monetary and Fiscal Policy Indicators with respect to Maturity of Credit ...................................................................................................... 27

Table 8. Sum of Coefficients on Monetary and Fiscal Policy Indicators for Foreign Banks. $\underline{28}$

Table 9. Sum of Liquidity and Retail Rank Coefficients Estimated in Step-1 ……………..... 31 


\section{INTRODUCTION}

Both the Turkish banking sector and the overall economy have gone through considerable changes in the aftermath of the 2000-01 crisis. In the banking sector, on top of the massive consolidation and restructuring, regulations and supervision were improved, share of state ownership was reduced, distortionary taxes were reduced, and new financial products such as mortgages and associated prudential regulation were introduced. The macroeconomic scene also has changed dramatically with monetary authorities adopting an inflation targeting policy to reduce the double-digit inflation rate (around 70 percent by the end of 2001) to single digits. Additionally, the government has applied a prudent fiscal policy to reduce its overall debt, with a commitment to run a primary surplus of 6.5 percent of GDP. ${ }^{2}$

Such changes bring attention to an old but fundamental question: How do monetary and fiscal policies affect availability of credit to the private sector? In particular, is the bank lending channel for monetary transmission effective? ${ }^{3}$ And, does a decline in government financing needs make more loans accessible for private residents? A detailed study of loan supply response to macroeconomic policy shocks in this period in Turkey is interesting as the magnitude of changes in the policy stance could facilitate identification of these channels in effect. Moreover, the 2000-01 crisis provides a natural experiment in the sense that the changes in the policy stance constitute a structural break that the banks had to adapt to as opposed to being mere responses to ongoing economic and financial conditions. Arguably, endogeneity of policy is less of a problem in this setting because policies have been designed to act as anchors.

This paper analyzes the impact of monetary and fiscal policies on Turkish banks' lending activities in the post-crisis period. In particular, we show that changes in monetary policy have affected credit growth through their impact on the cost of external funds and liquidity constraints. In addition, following the shift in government policies, banks have adapted to a new economic environment by moving the weight in their operations from money market trades to retail banking activities and extending more credit to the private sector.

To analyze the impact of monetary policy on credit growth in Turkey, we build upon the methodology introduced by Kashyap and Stein (2000), from now on referred as KS. KS (2000) test the impact of monetary policy on loan growth using a two-step regression approach. The argument is that banks cannot without friction substitute sources to fund loans to make up for a monetary-policy-induced shortage in available funds. But not all banks are constrained at the same degree: the effect of monetary policy on lending should be more pronounced for some banks than for others. In particular less liquid banks and smaller banks, which are more likely to have limited access to external funding sources, should respond

\footnotetext{
${ }^{2}$ This is in terms of the old GDP series, corresponding to about 5 percent of GDP with the revised GDP series.

${ }^{3}$ There are, of course, other channels for monetary policy transmission. These include (i) the interest rate channel, where lower real interest rates boost consumption and investment; and (ii) the balance sheet channel, where rising asset prices due to lower interest rates increase the value of collateral and improve borrower quality. In this paper, we focus only on the bank lending channel.
} 
more strongly to changes in the monetary policy stance. Hence, one can use this crosssectional variation to detect the impact of monetary policy on loan supply.

Building on the KS methodology on monetary transmission, we also consider the effects of fiscal policy changes on bank lending. These are likely to be particularly important in Turkey, and other emerging markets, where large government deficits tend to be financed through short-term debt in domestic markets. Under such circumstances, economic theory posits that the government "crowds out" the private sector in credit markets; hence, lax fiscal policy would be related to a slow-down in the growth of bank credit to the private sector. Following the same approach of utilizing the cross-sectional variation to identify the impact of fiscal tightening on loan supply, we argue that banks that have a retail-banking focus in place should have larger loan growth when contractionary fiscal policy comes into effect while those that used to be more active in funding the budget deficit would have a harder time adjusting to the new economic environment. This argument is supported by the findings of economic literature on relationship banking, which conjectures that the cost of obtaining private information about the borrower and the benefits of repeated deals with the same party make it worthwhile to invest in creating such relationships. ${ }^{4}$ For our purposes, banks that rely less on income generated by money market operations, financing government debt, and more on income generated through loans to private clients are more likely to develop relationships with these clients. Therefore, one could look at the differences among banks with varying reliance on money market operations in their business model and, as a result, different weight of loans to the private sector in their overall portfolio, to find out the impact of fiscal discipline on bank loan supply to the private sector.

Our main specification asserts that loan supply is a function of monetary and fiscal variables. Under this specification, a contractionary monetary policy reduces banks' loan supply; and this effect would be more pronounced for small banks with lower liquidity ratios, as they cut back down on their lending more than other banks, when faced with monetary tightening. Such a finding would provide evidence in support of bank lending channel being in effect. A contractionary fiscal policy, on the other hand, would free bank assets previously invested in government securities, and hence, would lead to an increase in loan supply. This effect would be more pronounced for banks that have already established a presence in the private loan market. In other words, crowding-out would be diminished and the banks that have a comparative advantage in catering to the private sector would benefit from the contractionary fiscal policy more than others can. Using quarterly data on all banks that have been active in Turkey between 2002Q4 and 2008Q1, we test these assertions. ${ }^{5}$

\footnotetext{
${ }^{4}$ For more on relationship banking, see Freixas (2005) and references therein.

${ }^{5}$ We limit the time period to these dates as we aim to exclude the periods of distress while maintaining comparability of reported data through time. Restructuring and review of reporting requirements as well as rehaul of accounting standards took a couple of years to complete following the 2000-01 crisis. Hence, we start our sample period in 2002Q4. Effects of the 2007-08 credit crisis that broke out in the United States begun to be felt in the Turkish financial sector as early as the second quarter of 2008 with market value of financial sector stocks plummeting from USD 115 billion at the end of 2007 to USD 60 billion in June 2008. Therefore, we stop our sample period in 2008Q1 so that the results are not affected by the shocks due to the global financial crisis.
} 
The results, as expected, show that a contractionary monetary policy restricts, in particular, the domestic-currency-denominated and medium-to-long term credit supply of banks. On the other hand, it has little power in restricting the foreign-currency-denominated loans and has very limited impact on restricting the loan supply of foreign banks. Furthermore, a monetary contraction leads banks to extend more credit in shorter maturity since short-term credit is less likely to induce maturity mismatches, and hence, is less sensitive to a decline in funding sources. In fact, it is likely to be the case that banks substitute shorter for longer maturity loans in an effort to keep the overall credit supply less affected and/or to maintain their liquidity ratios at the desired level. Nevertheless, these findings are statistically weak, supporting the view that bank lending channel of monetary policy is not very strong in Turkey.

Similarly, fiscal policy impact varies depending on bank ownership and the type of loans. The results show that fiscal policy crowds out only the domestic-currency-denominated credit provided by domestic banks, indicating that that it has limited impact on foreign banks and credit extended in foreign currencies. Similar to a contractionary monetary policy, fiscal tightening leads banks to extend more of shorter term credit; and undermines the importance of retail banking as a business focus, since these loans require less scrutiny when it comes to credit risk assessment.

Hence, in the absence of compelling evidence, we conclude that bank lending channel of monetary policy transmission is weak in Turkey while fiscal policy has only some impact on certain type of loans extended by a particular group of banks. This evidence adds to the literature that looks into the bank lending channel in emerging markets such as Şengönül and Thorbecke (2005), Arena, Vázquez, and Reinhart (2007), and Brooks (2007), challenging some of the results reported in these papers on the existence of a bank lending channel of monetary policy transmission mechanism in Turkey and providing new insights on whether different group of banks respond to changes in policy stance differently. And, to the best of our knowledge, this is one of the first papers analyzing the impact of fiscal policy on bank credit to the private sector and the first to do so in a setting that distinguishes between supply- and demand-side effects and isolates the supply-side response. ${ }^{6}$ Moreover, we employ a seemingly unrelated equation framework recognizing the interaction between monetary and fiscal policies.

The rest of the paper is organized as follows. Section II gives a brief account of the Turkish economy and the banking sector as well as the literature on macroeconomic policies and bank lending activity in juxtaposition to this study. Section III describes the data and lays out the methodology to address the questions raised here. We present the empirical results in Section IV. Finally, Section V concludes.

\footnotetext{
${ }^{6}$ Hauner (2008) looks at the impact of credit-to-government on financial deepening, measured as the growth in bank-credit-to-GDP ratio, in a large set of countries; and finds a sizeable negative effect in developing countries but no impact in advanced economies. Degirmen (2007) shows that, in the 1990s, public sector borrowing led to a decrease in lending by state-owned banks in Turkey.
} 


\section{BACKGROUND}

\section{A. Turkish Economy and Banking Sector}

Turkey has a long history of double-digit and persistent inflation rate accompanied with frequently and severely disrupted growth dynamics (Figure 1). High level of public involvement in the economy has been blamed by many as one of the major sources of these severe disruptions in the economy. Large size of the government, coupled with an ineffective tax system, led public debt to become one of the highest among the country's peers ${ }^{7}$ and government policies often aimed little more than maintaining the ability to roll over the debt in the short run. Banking sector, as a result, heavily relied on money market operations to finance public sector borrowing in their business model rather than focusing on retail banking activities (Figure 2). This business model left banks severely exposed to direct interest rate and indirect exchange rate risks, and as policy actions responded to economic fluctuations, not surprisingly, macroeconomic shocks hit banks hard and lending to the private sector exhibited severe and frequent oscillations (Figure 3).

Figure 1. Inflation and Growth Dynamics, 1964-2008

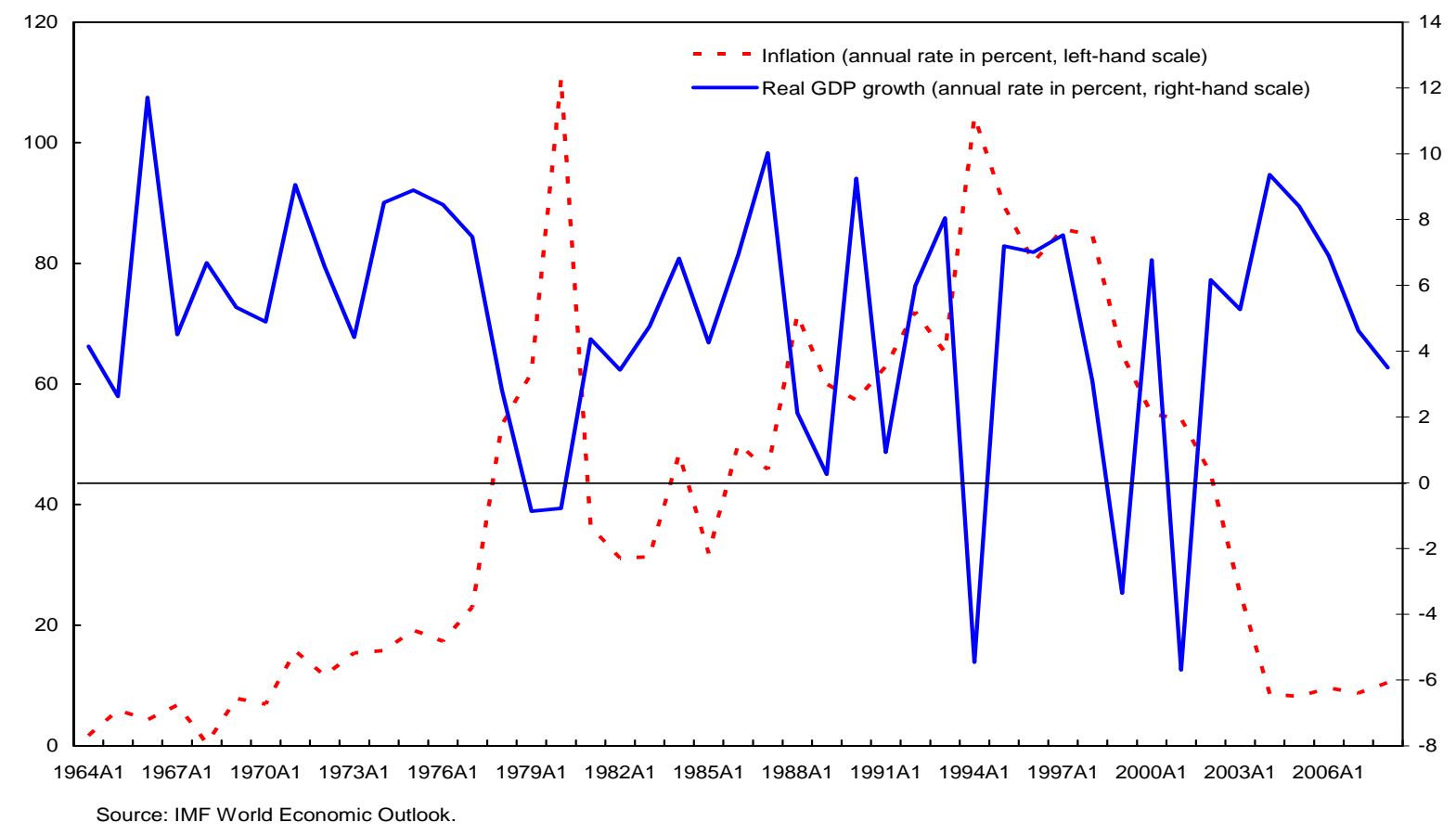

\footnotetext{
${ }^{7}$ General government expenditures account for roughly a third of GDP. Public debt stock came down from 74 percent at end-2002 to 39 percent at end-2007.
} 
Figure 2. Government Debt Financing by Banks

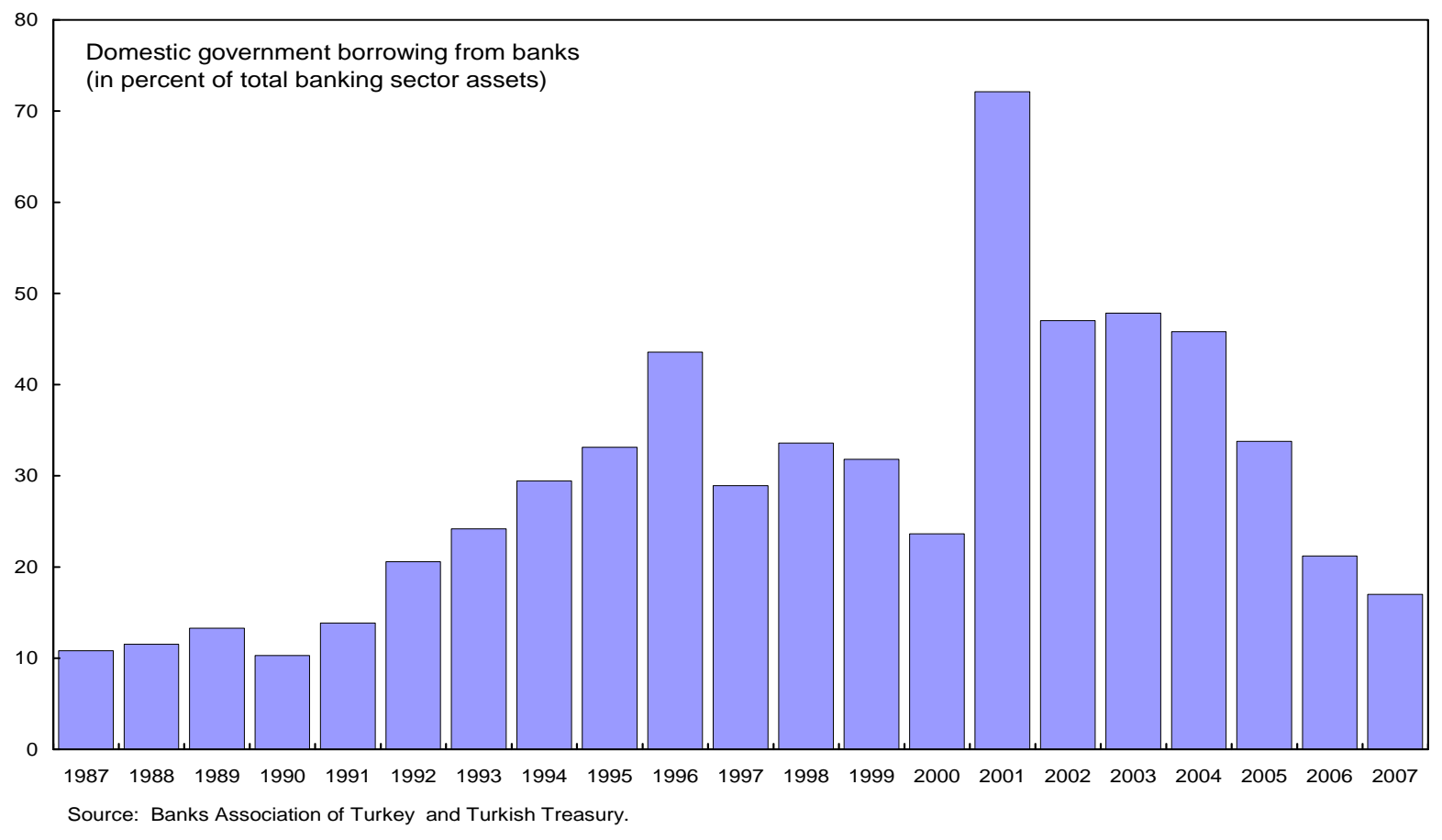

Figure 3. Bank Credit to the Private Sector and Crises

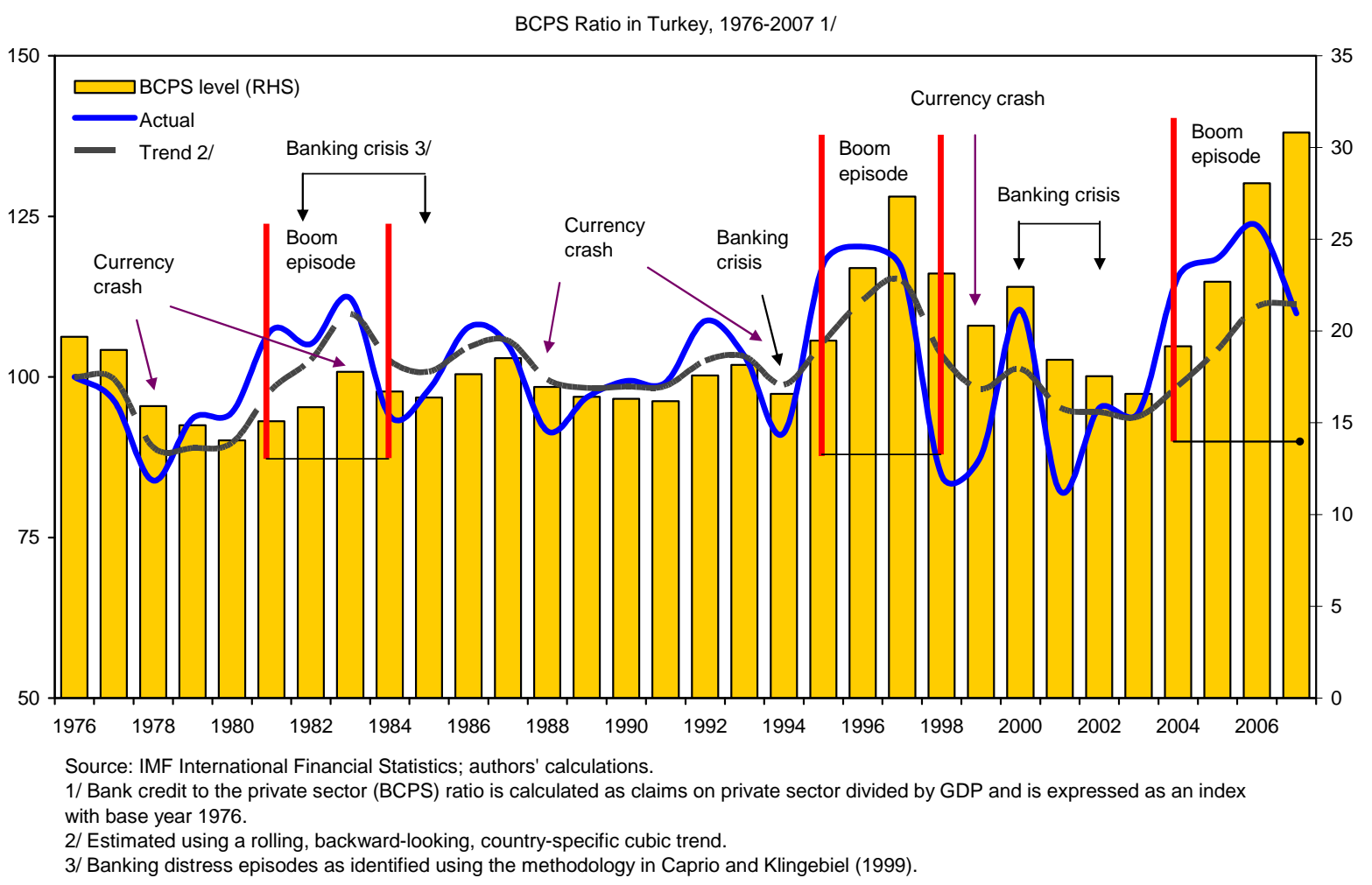


Turkey's financial system and banking sector are virtually synonymous with respect to many of the transactions and activities carried out in both money and capital markets: banks and assets of the banking sector constitute more than 85 percent of total financial system assets as of end-2007. The 2000-01 crisis had several reasons, ${ }^{8}$ but the major problems that underlied the turmoil in the banking sector were (i) the unsustainable business model relying on shortterm financing of the large public sector debt, and (ii) inadequate risk management practices, poor corporate governance, and lax supervision. Following the crisis, the monetary and fiscal policies changed drastically. In 2001, the government set out an IMF-backed 3-year stabilization program and committed to strengthen its balance sheet position. ${ }^{9}$ Concurrently, the central bank adopted a strong disinflation program and the double-digit inflation rate, which was around 70 percent at the time, was reduced to single digits by the end of 2004 .

The banking sector also went through considerable change at the back of initiatives to increase resiliency and supervision quality. A series of banking laws, bringing regulations closer to the European Union and other international standards, has been enacted. In June 1999, the Banking Regulation and Supervision Agency (BRSA), with financial and administrative autonomy, was established to take over as the main regulatory and supervisory body, a role played by the Treasury and the Central Bank prior to the changes in the law. With the establishment of the BRSA, the Savings Deposits Insurance Fund (SDIF), previously under the authority of the Central Bank, started to operate under the administration of the BRSA. Later on, in December 2003, the management of the SDIF was separated from the management of the BRSA. The voluntary out-of-court debt restructuring ("the Istanbul approach") introduced in January 2002 also helped restore banking sector solvency. In November 2005, the supervisory system was further strengthened by the passing of additional regulations concerning foreign exchange exposures, capital adequacy, internal control and risk management, lending limits, conditions on bank ownership and corporate governance, consolidated and cross-border supervision of banks, accounting standards for financial disclosure purposes, prudential reporting, and loan loss provisioning.

As of December 2007, there were 46 banks operating in Turkey, with deposit banks accounting for the bulk while development and investment banks show a small existence

\footnotetext{
${ }^{8}$ The crisis erupted in November 2000 when Demirbank, a medium-sized financial institution, liquidated a large amount of government securities as it was unsuccessful in rolling over its overnight liabilities. The collapse in the value of government securities triggered capital outflows and a subsequent fall in international reserves. The crisis revealed the maturity mismatches and exposure of the banking sector to interest and exchange rate risks. After the initial response of extending guarantees on deposits and other bank liabilities in December, continued deterioration in economic conditions and weak policy implementation, including tensions in the political scene, ignited yet another capital outflow in February 2001. Overnight interest rates spiked and liquidity injections to contain those destabilized the crawling peg. Ultimately, the peg was abandoned and the fiscal cost of the crisis reached 32 percent of GDP while output loss is estimated to be 16 percent of GDP.

${ }^{9}$ Turkey had several programs with the IMF prior to 2001; the 1999 one also included a stabilization program and reform of the banking sector among its priorities.
} 
Table 1. Banks by Market Share

\begin{tabular}{|c|c|c|c|c|c|c|c|}
\hline & \multicolumn{3}{|c|}{ Market share based on } & & \multicolumn{3}{|c|}{ Market share based on } \\
\hline & Total assets & Total loans & $\begin{array}{c}\text { Total } \\
\text { deposits }\end{array}$ & & Total assets & Total loans & $\begin{array}{c}\text { Total } \\
\text { deposits }\end{array}$ \\
\hline Deposit banks & 96.6 & 95.9 & 100.0 & Foreign banks & 15.0 & 18.8 & 14.4 \\
\hline \multirow[t]{2}{*}{ Domestic public banks } & 29.2 & 22.5 & 35.8 & ABN AMRO Bank N.V. & 0.2 & 0.1 & 0.1 \\
\hline & & & & Arap Türk Bankası A.Ș. & 0.1 & 0.0 & 0.0 \\
\hline Türkiye Cumhuriyeti Ziraat Bankası & 14.4 & 7.7 & 19.1 & Bank Mellat & 0.0 & 0.0 & 0.0 \\
\hline Türkiye Halk Bankası A.Ş. & 7.2 & 6.5 & 8.6 & Citibank A.Ş. & 0.7 & 0.7 & 0.9 \\
\hline \multirow[t]{2}{*}{ Türkiye Vakıflar Bankası T.A.O. } & 7.6 & 8.4 & 8.1 & Denizbank A.Ş. & 2.7 & 3.7 & 2.6 \\
\hline & & & & Deutsche Bank A.Ș. & 0.1 & 0.1 & 0.1 \\
\hline \multirow[t]{2}{*}{ Domestic private banks } & 52.3 & 54.6 & 49.7 & Eurobank Tekfen A.Ş. & 0.5 & 0.3 & 0.3 \\
\hline & & & & Finans Bank A.Ş. & 3.7 & 5.1 & 3.6 \\
\hline Adabank A.S. & 0.0 & 0.0 & 0.0 & Fortis Bank A.S. & 1.8 & 2.0 & 1.6 \\
\hline Akbank T.A.Ș. & 12.2 & 13.2 & 11.5 & Habib Bank Limited & 0.0 & 0.0 & 0.0 \\
\hline Alternatif Bank A.Ş. & 0.5 & 0.7 & 0.5 & HSBC Bank A.Ş. & 2.4 & 3.3 & 2.1 \\
\hline Anadolubank A.Ş. & 0.5 & 0.6 & 0.5 & JPMorgan Chase Bank N.A. & 0.0 & 0.0 & 0.0 \\
\hline Şekerbank T.A.Ş. & 1.1 & 1.3 & 1.2 & Millenium Bank A.Ş. & 0.2 & 0.3 & 0.3 \\
\hline Tekstil Bankası A.Ş. & 0.5 & 0.7 & 0.4 & Oyak Bank A.Ş. & 2.2 & 3.0 & 2.5 \\
\hline Turkish Bank A.Ş. & 0.1 & 0.0 & 0.1 & Société Générale (SA) & 0.1 & 0.0 & 0.0 \\
\hline Türk Ekonomi Bankası A.Ş. & 2.1 & 2.4 & 2.0 & Turkland Bank A.Ş. & 0.1 & 0.1 & 0.1 \\
\hline Türkiye Garanti Bankası A.Ș. & 12.0 & 13.3 & 11.0 & Unicredit Banca di Roma S.p.A. & 0.0 & 0.0 & 0.0 \\
\hline Türkiye İș Bankası A.Ș. & 14.3 & 12.1 & 13.6 & WestLB AG & 0.2 & 0.0 & 0.2 \\
\hline \multirow{2}{*}{ Yapı ve Kredi Bankası A.Ş. } & 9.0 & 10.2 & 9.0 & & & & \\
\hline & & & & Development and investment banks & 3.4 & 4.1 & - \\
\hline \multirow[t]{2}{*}{ Banks under SDIF } & 0.2 & 0.0 & 0.0 & & & & \\
\hline & & & & BankPozitif Kredi ve Kalkınma Bankası A.Ş. & 0.2 & 0.3 & - \\
\hline \multirow[t]{12}{*}{ Birleşik Fon Bankası A.Ş. } & 0.2 & 0.0 & 0.0 & Calyon Yatırım Bankası Türk A.Ş. & 0.0 & 0.0 & - \\
\hline & & & & Çalık Yatırım Bankası A.Ş. & 0.0 & 0.0 & - \\
\hline & & & & Diler Yatırım Bankası A.Ş. & 0.0 & 0.0 & - \\
\hline & & & & GSD Yatırım Bankası A.Ş. & 0.0 & 0.0 & - \\
\hline & & & & İler Bankası & 1.0 & 1.5 & - \\
\hline & & & & İMKB Takas ve Saklama Bankası A.Ş. & 0.2 & 0.0 & - \\
\hline & & & & Merrill Lynch Yatırım Bank A.Ş. & 0.0 & 0.0 & - \\
\hline & & & & Nurol Yatırım Bankası A.Ş. & 0.0 & 0.0 & - \\
\hline & & & & Taib Yatırım Bank A.Ş. & 0.0 & 0.0 & - \\
\hline & & & & Türk Eximbank & 0.7 & 1.2 & - \\
\hline & & & & Türkiye Kalkınma Bankası A.Ş. & 0.1 & 0.1 & - \\
\hline & & & & Türkiye Sınai Kalkınma Bankası A.Ș. & 0.9 & 0.9 & - \\
\hline
\end{tabular}


Table 2. Banks in the Sample

\begin{tabular}{|c|c|c|c|c|c|c|c|}
\hline Bank Name & Type & Ownership & Notes & Bank Name & Type & Ownership & Notes \\
\hline ABN AMRO Bank N.V. & Deposit & Foreign branch & & JPMorgan Chase Bank N.A. & Deposit & Foreign branch & \\
\hline Adabank A.Ş. & Deposit & Domestic private & & Koçbank A.Ş. & Deposit & Domestic private & Acquired by Yapı ve Kredi Bankası A.Ş. in 2006 \\
\hline Ak Uluslararası Bankası A.Ş. & Deposit & Foreign subsidiary & Acquired by Akbank T.A.Ş. in 2005 & Merrill Lynch Yatrim Bank A.Ş. & Dev. \& Inv. & Foreign subsidiary & $\begin{array}{l}\text { Used to be a domestic private bank (Tat Yatrim } \\
\text { Bankasi A.S.), sold to Merrill Lynch European } \\
\text { Asset Holdings, Inc. in } 2006\end{array}$ \\
\hline Akbank T.A.Ş. & Deposit & Domestic private & & Millennium Bank A.Ș. & Deposit & Foreign subsidiary & \\
\hline Alternatif Bank A.Ş. & Deposit & Domestic private & & Nurol Yatırım Bankası A.Ș. & Dev. \& Inv. & Domestic private & \\
\hline Anadolubank A.Ş. & Deposit & Domestic private & & Oyak Bank A.Ş. & Deposit & Foreign subsidiary & $\begin{array}{l}\text { Used to be a domestic private bank, sold to ING } \\
\text { Bank N.V. in } 2008\end{array}$ \\
\hline Arap Türk Bankası A.Ș. & Deposit & Foreign subsidiary & & Pamukbank T.A.S. & Deposit & Domestic public & $\begin{array}{l}\text { Used to be a domestic private bank, transferred to } \\
\text { SDIF in } 2002 \text { and then acquired by Türkiye Halk } \\
\text { Bankası A.Ş. in } 2004\end{array}$ \\
\hline Banca di Roma S.P.A. & Deposit & Foreign branch & & Şekerbank T.A.S. & Deposit & Domestic private & $\begin{array}{l}34 \text { percent of shares sold to BTA Bank of } \\
\text { Kazakhstan in } 2006\end{array}$ \\
\hline Bank Mellat & Deposit & Foreign branch & & Société Générale (SA) & Deposit & Foreign branch & \\
\hline BankPozitif Kredi ve Kalkınma Bankası A.Ş. & Dev. \& Inv. & Foreign subsidiary & & Taib Yatırım Bank A.Ș. & Dev. \& Inv. & Foreign subsidiary & \\
\hline Birleşik Fon Bankası A.Ş. & Deposit & Domestic public & $\begin{array}{l}\text { Created through merger of several banks } \\
\text { following the crisis, under SDIF management }\end{array}$ & Tekfenbank A.Ş. & Deposit & Foreign subsidiary & $\begin{array}{l}\text { Used to be a domestic private bank, sold to } \\
\text { Eurobank EFG Holding (Luxembourg) S.A. in } \\
2007\end{array}$ \\
\hline Çalık Yatrım Bankası A.Ş. & Dev. \& Inv. & Domestic private & $\begin{array}{l}\text { Changed name to Aktif Yatrrm Bankası A.Ş. in } \\
2008\end{array}$ & Tekstil Bankası A.Ş. & Deposit & Domestic private & \\
\hline Calyon Bank Türk A.Ş. & Dev. \& Inv. & Foreign subsidiary & & Toprakbank A.Ş. & Deposit & Domestic private & Dissolved in 2002 \\
\hline Citibank A.Ş. & Deposit & Foreign subsidiary & Transformed from branch to subsidiary in 2004 & Türk Ekonomi Bankası A.Ş. & Deposit & Domestic private & $\begin{array}{l}42 \text { percent of shares sold to BNP Paribas of } \\
\text { France in } 2005\end{array}$ \\
\hline Credit Lyonnais Turkey & Deposit & Foreign branch & Acquired by Calyon Bank Türk A.Ș. in 2004 & Türk Eximbank & Dev. \& Inv. & Domestic public & \\
\hline Credit Suisse First Boston & Deposit & Foreign branch & Dissolved in 2003 & Turkish Bank A.Ș. & Deposit & Domestic private & \\
\hline Denizbank A.Ş. & Deposit & Foreign subsidiary & $\begin{array}{l}\text { Used to be a domestic private bank, sold to Dexia } \\
\text { (Belgium-France partnership) in } 2006\end{array}$ & Türkiye Cumhuriyeti Ziraat Bankası A.Ș. & Deposit & Domestic public & \\
\hline Deutsche Bank A.Ș. & Deposit & Foreign subsidiary & $\begin{array}{l}\text { Used to be an investment bank, licensed to take } \\
\text { deposits in } 2004\end{array}$ & Türkiye Garanti Bankası A.Ș. & Deposit & Domestic private & \\
\hline Diler Yatrrm Bankası A.Ș. & Dev. \& Inv. & Domestic private & & Türkiye Halk Bankası A.Ș. & Deposit & Domestic public & \\
\hline Fiba Bank A.Ș. & Deposit & Domestic private & Acquired by Finans Bank A.Ş. in 2003 & Türkiye İmar Bankası T.A.Ş. & Deposit & Domestic private & Dissolved in 2003 \\
\hline Finans Bank A.Ş. & Deposit & Foreign subsidiary & $\begin{array}{l}\text { Used to be a domestic private bank, sold to } \\
\text { National Bank of Greece S.A. in } 2006\end{array}$ & Türkiye İş Bankası A.Ş. & Deposit & Domestic private & \\
\hline Fortis Bank A.Ș. & Deposit & Foreign subsidiary & $\begin{array}{l}\text { Used to be a domestic private bank (Türk Dış } \\
\text { Ticaret Bankası A.Ş.), sold to Fortis Bank NV-SA } \\
\text { in } 2005\end{array}$ & Türkiye Kalkınma Bankası A.Ș. & Dev. \& Inv. & Domestic public & \\
\hline $\begin{array}{l}\text { GSD Yaturm Bankası A.S. } \\
\text { Habib Bank Limited }\end{array}$ & Dev. \& Inv. & Domestic private & & Türkiye Sinai Kalkınma Bankası A.Ş. & Dev. \& Inv. & Domestic private & \\
\hline $\begin{array}{l}\text { Habib Bank Limited } \\
\text { HSBC Bank A.S. }\end{array}$ & $\begin{array}{l}\text { Deposit } \\
\text { Deposit }\end{array}$ & $\begin{array}{l}\text { Foreign branch } \\
\text { Foreign subsidiary }\end{array}$ & & $\begin{array}{l}\text { Türkiye Vakiflar Bankası T.A.O. } \\
\text { Turkland Bank A.Ș. }\end{array}$ & $\begin{array}{l}\text { Deposit } \\
\text { Deposit }\end{array}$ & $\begin{array}{l}\text { Domestic public } \\
\text { Foreign subsidiary }\end{array}$ & $\begin{array}{l}\text { Used to be a domestic private bank (MNG Bank } \\
\text { A.S.), sold to Arap Bank Plc and BankMed in }\end{array}$ \\
\hline Illler Bankası & Dev \& Inv. & Domestic public & & WestLB AG & Deposit & Forejon hranch & \\
\hline İMKB Takas ve Saklama Bankası A.Ş. & Dev. \& Inv. & Domestic private & $\begin{array}{l}\text { Engaged in specialized banking services for } \\
\text { capital markets }\end{array}$ & Yapı ve Kredi Bankası A.Ş. & Deposit & Domestic private & \\
\hline ING Bank N.V. & Deposit & Foreign branch & Dissolved in 2003 & & & & \\
\hline
\end{tabular}


(Table 1).$^{10}$ Domestic private banks constitute slightly more than half of the banking sector in terms of market share. The banking sector assets amount to around 60 percent of GDP while the whole financial system assets are about 70 percent of GDP.

While both the relatively large number of banks and the Herfindahl-Hirschman index, at 0.09, suggest a high degree of competition, careful inspection reveals that the share of top 5 banks command almost two-thirds of the market. In addition to high concentration, the banking sector, despite the quick wave of acquisitions of previously domestically owned banks by foreigners following the crisis, remains mostly domestic, especially relative to other emerging markets (BIS 2006, IMF 2007). Public involvement also remains high comprising around a third of the sector assets.

As Table 2 shows, the sample of banks includes several cases of mergers and acquisitions as well as exit of some banks as a consequence of the restructuring efforts. In preparation for the empirical analysis, we pay particular attention to reflecting these changes (more details on this issue are in the Data section).

The capital structures of the banks in the system were the core of the restructuring program (Figure 4). A three-phase audit revealed the real capital needs of private banks, and once identified, the capital structures of banks having capital shortages were strengthened. The average capital adequacy ratio of the whole sector as of December 2007 stood at 18.9 percent. The results of the financial and operational restructuring of banking system have been observed as an improvement in the profitability ratios of the whole sector.

Figure 4. Restructuring of the Banking System Capital Adequacy

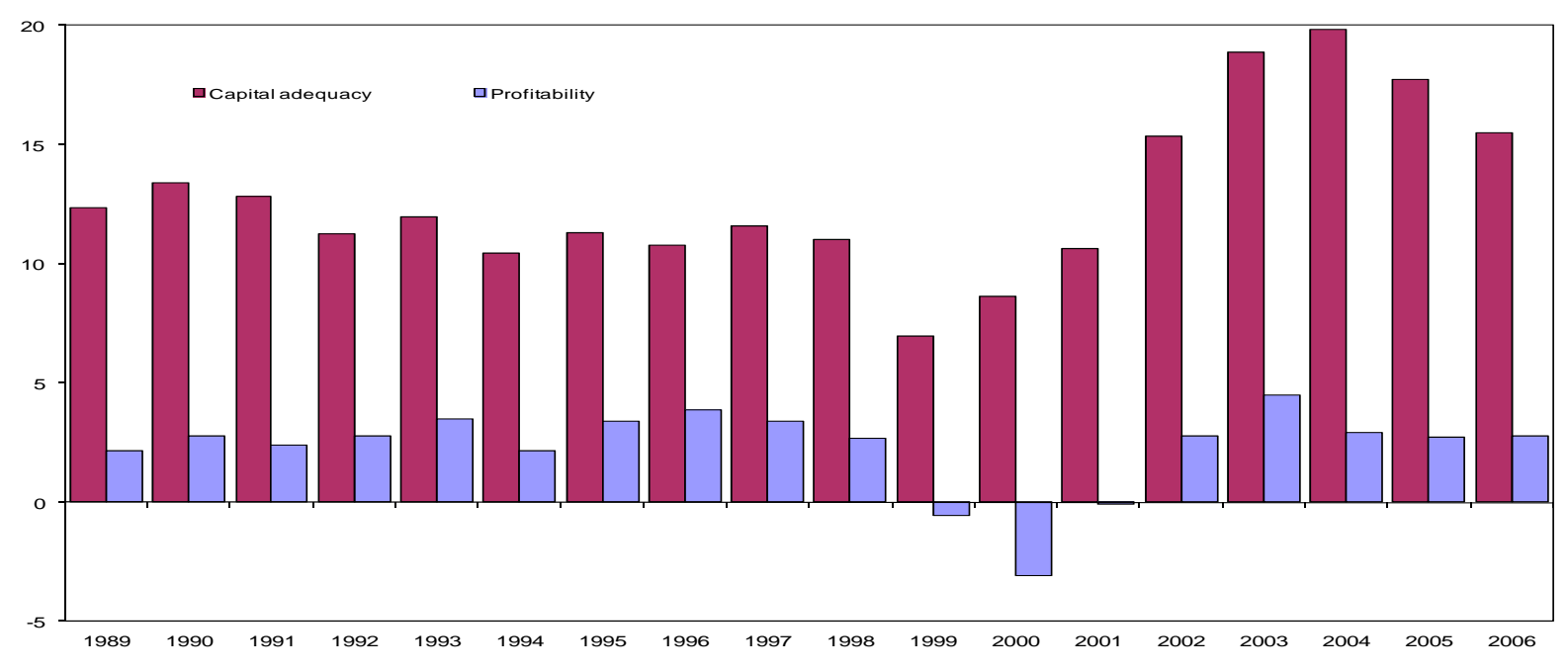

Source: Authors' calculations based on bank-by-bank data provided by the Bankers Association of Turkey.

\footnotetext{
${ }^{10}$ In our dataset, there are 55 banks. The 9 banks that make up the difference had been subject to reorganizational changes during the sample period. We still include these in the empirical analysis to minimize survivalship bias. Also note that the sample excludes participation banks, e.g. Islamic banks.
} 


\section{B. Related Literature}

There is a substantial body of theoretical and empirical research indicating that monetary policy transmits to the economy in channels other than the straightforward interest rate channel. Bernanke and Gertler (1995) point out that the impact of monetary policy on the economy is larger than that implied by the interest elasticity of consumption and investment. The most-widely-studied explanation for this finding is the possibility that contractionary monetary policy decreases the core deposit funding for loans, leading some banks to reduce lending activity as they may be unable to raise funds elsewhere. In their seminal study, Kashyap and Stein (2000) look at this bank lending channel of monetary transmission mechanism for the U.S. commercial banks during the period from 1976 to 1993. They employ a two-step regression approach to estimate the effect of liquidity on loan growth and the impact of monetary policy on the liquidity of a bank. They show that monetary policy has significant effects on banks with less liquid balance sheets, and this effect is even stronger for small-sized banks. Şengönül and Willem (2005) apply the methodology introduced by Kashyap and Stein (2000) to Turkey during the period from1997 to 2001. They show that the lending channel of monetary transmission exists in Turkey, i.e., a contractionary monetary policy reduces funding sources for loans, and, therefore, bank lending to the private sector. Brooks (2007) studies the monetary transmission during the May-June 2006 financial turbulence in Turkey. By applying a difference-in-difference approach to a bank-level dataset, she shows that bank liquidity affects loan supply significantly. The fact that these two latter studies find stronger evidence of a statistically significant monetary policy transmission mechanism in Turkey could be that both studies focus on exceptional periods of macroeconomic or financial turmoil.

While the literature on the bank lending channel of monetary transmission mechanism is vast, less attention has been paid to the implications of fiscal policy on bank credit supply to the private sector. High level of public debt has been blamed as a major source of disruption (see, for instance, statements by Selcuk Demiralp, former Undersecretary of the Treasury in Turkey, cited in McHale, 2001) yet formal studies of these assertions are somewhat scant. Degirmen (2007) shows that, relying on descriptive statistics and impulse responses, public sector borrowing led to a decrease in lending by state-owned banks in Turkey during the 1990s. Our paper, in contrast, employs a different and more structured empirical approach to study the impact of fiscal policy changes. Hauner (2008) study the impact of credit to government on banking sector performance by using a panel data set for 142 countries. One of the measures of banking sector performance he uses is the growth rate of bank-credit-toGDP ratio, on which credit-to-government has a negative impact in developing countries. However, supply- and demand-side effects are not separated in arriving at this result.

\section{Data And Methodology}

\section{A. Data}

The bank-level data used in the analysis are obtained from the Banks Association of Turkey (TBB). In this dataset, information on balance sheets and income statements is available from 1988 onwards. However, between 1988 and 2007, Turkish banks have used three different accounting systems, and the financial statements have been reported in three different styles 
based on the detail level they contain. Only by December 2002, accounts have begun to be reported under consolidated and unconsolidated statements. Our analysis uses unconsolidated balance sheets and income statements, which are reported quarterly, from December 2002 to March 2008. ${ }^{11}$

Measures for monetary and fiscal policies are collected from the International Financial Statistics and World Economic Outlook publications of the IMF. However, a majority of the fiscal variables are available only at annual frequency. Therefore, we interpolate quarterly data from the annual series for the fiscal variables but, to ensure robustness, also gather information on fiscal policy variables at quarterly frequency from the Turkish Treasury.

Several data issues deserve detailed explanation. These concern inflation accounting, seasonality, mergers and acquisitions, outliers, and measurement of the key concepts, namely, liquidity and retail-banking focus ${ }^{12}$.

- $\quad$ Inflation adjustment: During the period between 2002 and 2004, banks in Turkey reported their balance sheet statements with respect to the inflation adjustment communiqué of the BRSA. By 2004, the chronically high inflation rate was reduced to single digits in Turkey, and hence, BRSA announced in its 2005/5 circular that inflation adjustment will be ceased from balance sheet reporting standards starting with the statements scheduled for release on January 1, 2005. Therefore, we adjust bank-year balance sheet data from 2005 onwards with the end-of-period inflation rate.

- $\quad$ Seasonality: The data we use is at quarterly frequency. As a result, especially with macroeconomic variables, seasonality is an important issue. As discussed in further detail in the Appendix, all variables that exhibit seasonal fluctuations are smoothed quarterly to eliminate these seasonality effects.

- $\quad$ Mergers and acquisitions: As noted earlier, there have been several mergers and acquisitions among the banks operating in Turkey. Mergers and acquisitions lead to sharp increases in the balance sheet of the acquiring bank during that accounting year. In order to eliminate the impact of these activities, we eliminate any bank-year observation with credit growth higher than 200 percent.

- $\quad$ Outliers: In the analysis of micro-level data, a commonly encountered issue is the impact of outliers on the outcome as the outliers can significantly influence the size and/or the sign of the estimated coefficients. In order to eliminate such a bias, we exclude outliers from the bank-level cross-sectional data. An outlier in this process is defined as any observation that is more than two standard deviations away from its

\footnotetext{
${ }^{11}$ Note that use of unconsolidated data may underestimate the impact on FX-denominated loans, which are often made by offshore branches. Our results do not change dramatically when consolidated data are used.

${ }^{12}$ The construction of all variables of interest is discussed further in Appendix B: Definition of Variables.
} 
time-variant mean, calculated over a rolling window to avoid mislabeling any trend that might exist in the data as an outlier.

- $\quad$ Measuring liquidity: Our empirical approach relies on identification of monetary policy impact on lending through liquidity constraints faced by banks. We employ two alternative liquidity measures. First is the liquidity measure as defined by the Banks Association of Turkey. This measure includes cash and balances with the central bank, financial assets where fair value change is reflected to income statement (net) with banks and other financial institutions, money market securities, and financial assets available for sale (net). As the 2007-08 financial crisis has proved, some of the items that were previously considered liquid may become rather illiquid during a market downturn. Therefore, our second measure includes only cash and balances with the central bank and money market securities, while excluding any other financial assets that may be subject to fire-sale prices.

- $\quad$ Retail-banking focus variable: We identify the fiscal policy impact on lending through across-bank variation in terms of the importance attached to retail banking in their income model. The measure we use as a proxy for the role of retail banking activities versus money market trades, which are dominated by government securities, in the bank's business model is constructed based on banks' loan activities in proportion to their overall assets. The retail-banking focus variable, thus, assigns values to each bank based on the ratio of its loan-to-asset ratio to the average loan-toasset ratio of the banking sector for a given year. The idea is that the banks that devote proportionately more resources to extending loans to the private sector are more likely to have and further expand their operational and informational advantages in dealing with the same or similar borrowers repeatedly. Hence, those banks that are ranked higher with respect to this measure would have a retail-banking focus in place. ${ }^{13,} 14$

\footnotetext{
${ }^{13}$ One could, of course, think of alternative measures to proxy for retail-banking focus. For instance, using income statements, one could look at the earnings from interest and earnings from fees \& commissions and build a measure based on how large these are relative to other income sources. Accounting rules and the level of detail in reporting, however, might create a wedge between these variables and the concept we are interested in since, for instance, commissions generally pertain to both loans and financial market transactions. In other words, such a measure would be subject to severe measurement error. Another potential measure could come directly from the bank's holdings of various securities. Nevertheless, public debt securities constitute the lion's share in the financial securities portfolio of Turkish banks and the fact that these are also considered to be a measure of liquidity might generate problems in the econometric analysis. Hence, we pass such alternative measures in favor of the rank variable based on loans to the private sector.

${ }^{14}$ Note that the loan-to-asset ratio may be higher in small banks, not necessarily because they have a comparative advantage in retail banking activities but reflecting the fact that large banks are the dominant players in the trading market place. In the regression analysis, we control for size to take such biases in the data into account.
} 
Table 3 provides the summary statistics for the dependent variable of interest, namely, credit growth, for all banks as well as for subcategories based on ownership. ${ }^{15}$ It is interesting to note that foreign banks, especially those incorporated as branches rather than subsidiaries, expanded credit faster than other banks did in this period. More strikingly, most of the acceleration in credit growth comes from foreign-currency-denominated loans. A final observation is that medium- and long-term credit has grown faster, probably reflecting the changes in the macroeconomic environment, in particular, the decline in uncertainty and improvement in risk management as a result of financial development. Another factor that might be in effect is the introduction of certain types of loans such as home mortgages in the sample period. Yet, another explanation behind this observation could be that lending standards have declined as in some cases extending the term of a loan might make it more affordable to less qualified borrowers. Given the initially low level of financial intermediation, we believe the latter explanation is less likely to have relevance compared to the first two.

Table 3. Summary Statistics

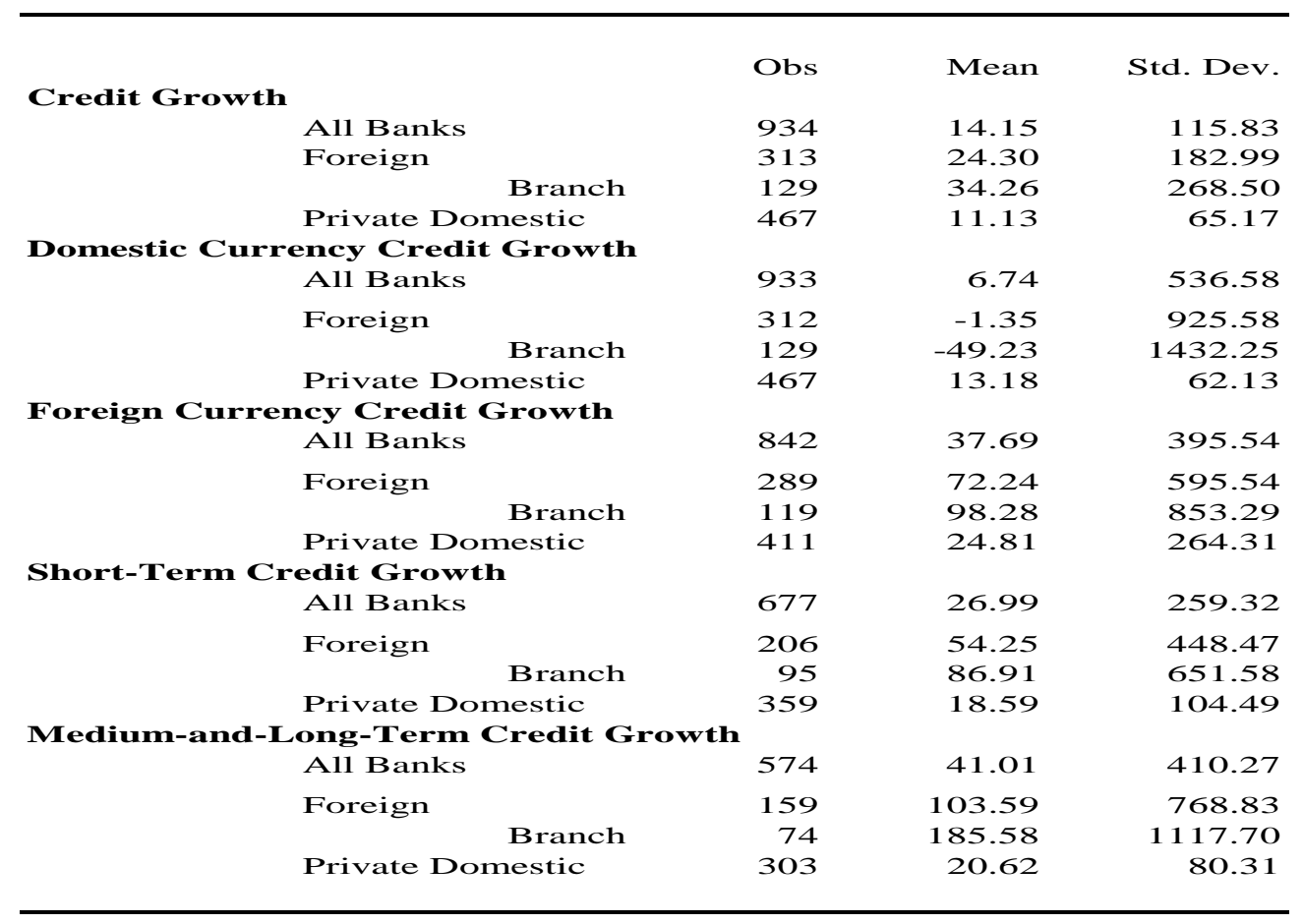

Table 4 shows the summary statistics for the other bank-level variables of interest. For the empirical analysis, our empirical approach requires enough cross-sectional variation in variables measuring liquidity and retail-banking focus. These statistics verify that there is enough variation to distinguish among banks and use the differences in their responses to policy changes to identify the impact of policies on lending from the supply side alone.

\footnotetext{
${ }^{15}$ This table summarizes the credit growth data as it is, without excluding any outliers.
} 
Table 4. Summary Statistics of Major Balance Sheet Items

\begin{tabular}{|c|c|c|c|}
\hline & Obs & Mean & Std. Dev. \\
\hline Total Assets & 1060 & 6,932,112 & $13,600,000$ \\
\hline \multicolumn{4}{|l|}{ As a Percent of Total Assets: } \\
\hline Domestic Currency Assets & 1060 & 64.22 & 29.39 \\
\hline Loans & 1019 & 36.24 & 23.33 \\
\hline Cash and Balances with the Central Bank & 1060 & 2.72 & 3.55 \\
\hline Money Market Securities & 681 & 10.55 & 16.40 \\
\hline Banks and Other Financial Institutions & 1060 & 13.28 & 16.45 \\
\hline Financial Assets (Marked-to-Market) & 932 & 12.20 & 18.80 \\
\hline Financial Assets Available for Sale & 820 & 12.37 & 12.67 \\
\hline Investments Held to Maturity & 561 & 13.39 & 15.62 \\
\hline Liquidity (1)* & 700 & 34.34 & 20.50 \\
\hline Liquidity (2)** & 681 & 12.91 & 16.61 \\
\hline \multicolumn{4}{|c|}{$\begin{array}{l}\text { * Liquidity (2), Financial assets (Marked-to-Market) and Financial assets available for sale } \\
\text { ** Cash and balances with the central bank, money market securities, and balances with banks and other financial } \\
\text { institutions }\end{array}$} \\
\hline
\end{tabular}

\section{B. Methodology}

Our first hypothesis is that contractionary monetary policy leads to a decline in credit growth, by increasing the cost of external funds, more for banks that face tighter liquidity constraints. More specifically, we test whether $\frac{\partial^{2} c g_{i t}}{\partial L_{i t} \partial M_{t}}<0$, where $c g_{i t}$ is the credit growth of bank $i$ at time $t, L_{i t}$ is the liquidity ratio and $M_{t}$ is the monetary policy at time $t$. Higher values of $L_{i t}$ indicate higher liquidity and lower values of $M_{t}$ indicate tighter monetary policy. In this context, $\left(\frac{\partial c g_{i t}}{\partial L_{i t}}\right)$ reflects the liquidity constraint of a bank; in other words, the hypothesis suggests that liquid banks can raise loans more easily than less liquid banks can. The second derivative, therefore, tells us that tighter monetary policy $\left(\downarrow M_{t}\right)$ should further increase the importance of liquidity constraint on bank lending $\left[\uparrow\left(\frac{\partial c g_{i t}}{\partial L_{i t}}\right)\right]$. These effects should be more pronounced for smaller banks.

Our second hypothesis is that contractionary fiscal policy increases credit growth, through freeing resources used to earn income from government securities, more for banks with retail-banking in business focus. More specifically, we test whether $\frac{\partial^{2} c g_{i t}}{\partial R_{i t} \partial F_{t}}<0$, where $R_{i t}$ is a measure for retail-banking focus of a bank and $F_{t}$ is the fiscal policy at time t. Higher 
values of $R_{i t}$ indicate more retail-banking focus whereas lower values of $F_{t}$ indicate tighter fiscal policy. The first derivative $\left(\frac{\partial c g_{i t}}{\partial R_{i t}}\right)$ signals the importance of business focus on credit growth to the private sector. In other words, banks with more retail-banking focus should be able to increase their loans to the private sector more and/or faster than others. The second derivative of credit growth shows that as fiscal policy tightens $\left(\downarrow F_{t}\right)$, corresponding to a decline in the government's need to use private sector savings, banks increase the amount that they lend to the private sector; and this effect would be higher for banks with retailbanking in focus $\left[\uparrow\left(\frac{\partial c g_{i t}}{\partial R_{i t}}\right)\right]$. Existing relationships with the client base would provide retail-focused banks a comparative advantage to extend more of these types of loans, and would lead them ahead of the banks that do not enjoy such pre-existing conditions.

We adopt a two-stage regression approach similar to the one used by Kashyap and Stein (2000) in order to quantify the impact of policy stance on lending. In addition to the monetary policy effect that Kashyap and Stein (2000) consider, we also look at the fiscal policy impact on credit: in step-one we estimate both $\frac{\partial c g_{i t}}{\partial L_{i t}}$ and $\frac{\partial c g_{i t}}{\partial R_{i t}}$. While estimating the impact of liquidity and retail-banking focus on credit growth, we also consider that banks may exhibit differences with respect to their ownership types. To take this into regard, we control for public, foreign and private domestic ownership types in step-one estimations. The following equation shows the model that we use in step-one estimations.

$$
c g_{i t}=c g_{i t-1}+\alpha_{t} L_{i t-1}+\gamma_{t} R_{i t-1}+\delta^{f} f_{i t}+\delta^{s} s_{i t}+\omega_{i t}
$$

In this equation, $c g_{i t}$ is the percentage change in the quarterly outstanding loans extended by bank $i$ in time $t ; f_{i t}$ and $s_{i t}$ are the foreign and state ownership dummies, respectively; and $\omega_{i t}$ is the heteroskedasticity-adjusted error term. The coefficients of interest are $\alpha_{t}$ and $\gamma_{t}$, which are the first derivatives of loan supply with respect to liquidity and retail-banking focus, respectively. After estimating $\alpha_{t}$ and $\gamma_{t}$ coefficients from Equation (1), we then jointly estimate the second derivates of credit growth by using the seemingly unrelated regression model below.

$$
\left[\begin{array}{l}
\hat{\alpha} \\
\hat{\gamma}
\end{array}\right]=\left[\begin{array}{cc}
X_{M} & 0 \\
0 & X_{F}
\end{array}\right]\left[\begin{array}{l}
\beta_{M} \\
\beta_{F}
\end{array}\right]+\left[\begin{array}{l}
\varepsilon_{M} \\
\varepsilon_{F}
\end{array}\right]
$$

where 


$$
\begin{aligned}
& X_{M} \beta_{M}= {\left[\begin{array}{ccccc}
1 & M_{1,0} & \ldots & M_{1,4} & t_{1} \\
\vdots & \vdots & & \vdots & \vdots \\
1 & M_{T, 0} & \ldots & M_{T, 4} & t_{T}
\end{array}\right]\left[\begin{array}{c}
c \\
\phi_{0} \\
\vdots \\
\phi_{4} \\
\delta^{t}
\end{array}\right] \text { for the univariate specification, and } } \\
& X_{M} \beta_{M}=\left[\begin{array}{cccccc}
1 & M_{1,0} & \ldots & M_{1,4} & t_{1} & g_{1} \\
\vdots & \vdots & & \vdots & \vdots & \vdots \\
1 & M_{T, 0} & \ldots & M_{T, 4} & t_{T} & g_{T}
\end{array}\right]\left[\begin{array}{c}
c \\
\phi_{0} \\
\phi_{4} \\
\delta^{t} \\
\delta^{g}
\end{array}\right] \text { for the bivariate specification; }
\end{aligned}
$$

and the error terms are such that

$$
\begin{aligned}
& E\left[\varepsilon \mid X_{M}, X_{F}\right]=0 \\
& E\left[\varepsilon \varepsilon^{\prime} \mid X_{M}, X_{F}\right]=\Omega
\end{aligned}
$$

In equation (2), $M_{t}$ and $F_{t}$ are the variables controlling for monetary and fiscal policy variables, respectively; $t_{t}$ is the time variable; and $g_{t}$ is the real GDP growth rate in that quarter. In step-two regressions, we consider five lags of the monetary and fiscal policy variables: all the lags from lag zero to lag four.

Note that the implicit assumption for the supply and demand effects to be separated in this framework is that all banks are affected in the same way by demand shocks.

\section{EMPIRICAL RESULTS}

\section{A. Baseline Results}

Table 5 presents the baseline results of our empirical analysis. In order to present the results in a compact manner, only one number (with the associated standard error) from each regression is shown: the sum of coefficient estimates of the monetary and fiscal policy indicators from the second step of the two-step estimation method given in equation (2). This number is reported both for the univariate and bivariate second-step estimation methods as depicted in equation (2). Regarding monetary and fiscal policy, we test whether the sum of the policy indicators are less than zero. The test statistics are reported with their associated heteroskedasticity-adjusted standard errors. Baseline results are reported for total loans and all banks in the sample while results for commercial banks only are shown separately given the fact that these constitute the bulk of the banking system and specialize in providing loans to both persons and corporations as opposed to the development and investment banks. In general, the test statistics for monetary policy indicators have negative signs as expected, however, with low significance levels. The test statistics for the fiscal indicators, on the other hand, does not obtain a robust sign in the baseline specification. 
Table 5 is divided into two panels. Panel A provides results using liquidity measure 1 in the first step estimation given in equation (1); and Panel B using liquidity measure 2. Liquidity measure 1 , which is frequently used in the banking literature, is a broader measure of liquidity. This measure includes cash and balances with the central bank; money market securities; banks and other financial institutions; financial assets marked-to-market; and financial assets available for sale. In Turkey, public sector debt securities constitute the majority of the banking sector financial assets; therefore, this variable may as well be affected by the impact of fiscal policy. In order to eliminate such concerns, step-one is also estimated using liquidity measure 2, which excludes financial assets; and the results from these estimations are shown on Table 5, Panel B. The policy variables have higher significance levels, when step-one regression is estimated using liquidity measure 2 . In fact the only significant results at five percent probability level are obtained through liquidity measure 2 in these estimations. This may indicate the biases that liquidity measure 1 may inhere due to its wide coverage. As aforementioned, liquidity measure 1 captures also holdings of government debt securities and could be seen as a hybrid measure of both liquidity and (inverse of) focus in retail banking activities. This could explain why the broader measure of liquidity does not give any significant coefficient estimates; therefore, the results reported in the rest of the tables rely on the narrower liquidity measure 2.

Each panel of Table 5 are divided into two sections: on the left-hand-side, each panel shows the sum of the coefficients on the monetary and fiscal policy indicators for all banks operating in Turkey, and, on the right-hand-side, the results are reported only for the sample of commercial banks. Even though small by share, some of the development and investment banks also provide credit in Turkey. Therefore, results are shown both for all banks, covering the credit growth in the banking sector in Turkey as a whole, and for commercial banks only, to observe any differences across bank types.

Further, each panel in Table 5 uses three variations of monetary and fiscal policy variables for the second step estimation of the two-step method. Monetary policy variables are inflation rate, discount rate and interbank money market lending rate. Fiscal policy measures are general government gross debt-to-GDP ratio, primary surplus as a percent of GDP and domestic general government debt-to-GDP. ${ }^{16}$ In results not reported for brevity, we also use the cyclically-adjusted deficit to capture only the discretionary part of the fiscal policy choice and the results remain virtually the same. Yet, given the caveats on estimating this measure of fiscal policy stance in Turkey, we only report the results with more conventional measures. Note that Turkey has been transitioning into inflation targeting during the sample period, making an analogous measure for monetary policy hard to define.

\footnotetext{
${ }^{16}$ As explained in the Methodology section, a decline in the monetary measure $\mathrm{M}$ and fiscal measure $\mathrm{F}$ indicate, respectively, monetary and fiscal tightening. In order to have uniformity in the sign of the coefficient estimates, inverse of discount rate, inverse of interbank money market lending rate and inverse of primary surplus ratio are used in the second-step estimations.
} 
Table 5. Sum of Coefficients on Monetary and Fiscal Policy Indicators

\begin{tabular}{|c|c|c|c|c|c|c|c|c|}
\hline \multicolumn{9}{|c|}{ PANEL A: Liquidity Measure 1} \\
\hline \multicolumn{5}{|c|}{ All Banks } & \multicolumn{4}{|c|}{ Commercial Banks } \\
\hline & \multicolumn{2}{|c|}{ Monetary Policy } & \multicolumn{2}{|c|}{ Fiscal Policy } & \multicolumn{2}{|c|}{ Monetary Policy } & \multicolumn{2}{|c|}{ Fiscal Policy } \\
\hline & Univariate & Bivariate & Univariate & Bivariate & Univariate & Bivariate & Univariate & Bivariate \\
\hline \multicolumn{9}{|c|}{ Step-2 Regressors: Annual Inflation Rate \& Debt-to-GDP } \\
\hline All Banks & $\begin{array}{l}0.0012 \\
(0.0137)\end{array}$ & $\begin{array}{l}0.0218 \\
(0.0185)\end{array}$ & $\begin{array}{l}0.0633 \\
(0.1018)\end{array}$ & $\begin{array}{l}0.0538 \\
(0.1021)\end{array}$ & $\begin{array}{r}-0.0150 \\
(0.0140)\end{array}$ & $\begin{array}{r}-0.0040 \\
(0.0197)\end{array}$ & $\begin{array}{l}0.0524 \\
(0.1074)\end{array}$ & $\begin{array}{l}0.0489 \\
(0.1094)\end{array}$ \\
\hline Small Banks & $\begin{array}{r}-0.0031 \\
(0.0167)\end{array}$ & $\begin{array}{l}0.0271 \\
(0.0225)\end{array}$ & $\begin{array}{l}0.0799 \\
(0.1113)\end{array}$ & $\begin{array}{l}0.0799 \\
(0.1110)\end{array}$ & $\begin{array}{r}-0.0123 \\
(0.0154)\end{array}$ & $\begin{array}{l}0.0077 \\
(0.0217)\end{array}$ & $\begin{array}{l}0.1282 \\
(0.1263)\end{array}$ & $\begin{array}{l}0.1248 \\
(0.1263)\end{array}$ \\
\hline \multicolumn{9}{|c|}{ Step-2 Regressors: Discount Rate \& Primary Surplus } \\
\hline All Banks & $\begin{array}{r}-1.2165 \\
(2.1110)\end{array}$ & $\begin{array}{r}-1.1811 \\
(2.1195)\end{array}$ & $\begin{array}{l}3.8062 \\
(3.8083)\end{array}$ & $\begin{array}{l}3.3884 \\
(3.7642)\end{array}$ & $\begin{array}{r}-0.4614 \\
(2.3461)\end{array}$ & $\begin{array}{r}-0.8496 \\
(2.2902)\end{array}$ & $\begin{array}{l}6.1568 \\
(5.6211)\end{array}$ & $\begin{array}{l}5.3187 \\
(5.5362)\end{array}$ \\
\hline Small Banks & $\begin{array}{l}1.6972 \\
(2.7161)\end{array}$ & $\begin{array}{l}1.7769 \\
(2.6985)\end{array}$ & $\begin{array}{l}3.6139 \\
(4.0439)\end{array}$ & $\begin{array}{l}3.2203 \\
(3.9402)\end{array}$ & $\begin{array}{l}2.0844 \\
(2.6330)\end{array}$ & $\begin{array}{l}1.8671 \\
(2.4892)\end{array}$ & $\begin{array}{l}6.7420 \\
(6.1835)\end{array}$ & $\begin{array}{l}6.0433 \\
(5.9815)\end{array}$ \\
\hline \multicolumn{9}{|c|}{ Step-2 Regressors: Interbank Money Market Rate \& Domestic Debt-to-GDP } \\
\hline All Banks & $\begin{array}{r}-0.5350 \\
(0.6609)\end{array}$ & $\begin{array}{r}-0.7512 \\
(0.7379)\end{array}$ & $\begin{array}{l}0.0653 \\
(0.0776)\end{array}$ & $\begin{array}{l}0.0986 \\
(0.0955)\end{array}$ & $\begin{array}{l}0.6185 \\
(0.5636)\end{array}$ & $\begin{array}{l}0.4491 \\
(0.6318)\end{array}$ & $\begin{array}{r}-0.0558 \\
(0.1236)\end{array}$ & $\begin{array}{r}-0.0118 \\
(0.1513)\end{array}$ \\
\hline Small Banks & $\begin{array}{l}0.0180 \\
(0.8374)\end{array}$ & $\begin{array}{r}-0.2286 \\
(0.9336)\end{array}$ & $\begin{array}{l}0.0784 \\
(0.0850)\end{array}$ & $\begin{array}{l}0.1101 \\
(0.1041)\end{array}$ & $\begin{array}{l}0.7817 \\
(0.7055)\end{array}$ & $\begin{array}{l}0.5610 \\
(0.7837)\end{array}$ & $\begin{array}{r}-0.0906 \\
(0.1329)\end{array}$ & $\begin{array}{r}-0.0219 \\
(0.1619)\end{array}$ \\
\hline
\end{tabular}

PANEL B: Liquidity Measure 2

All Banks

Commercial Banks

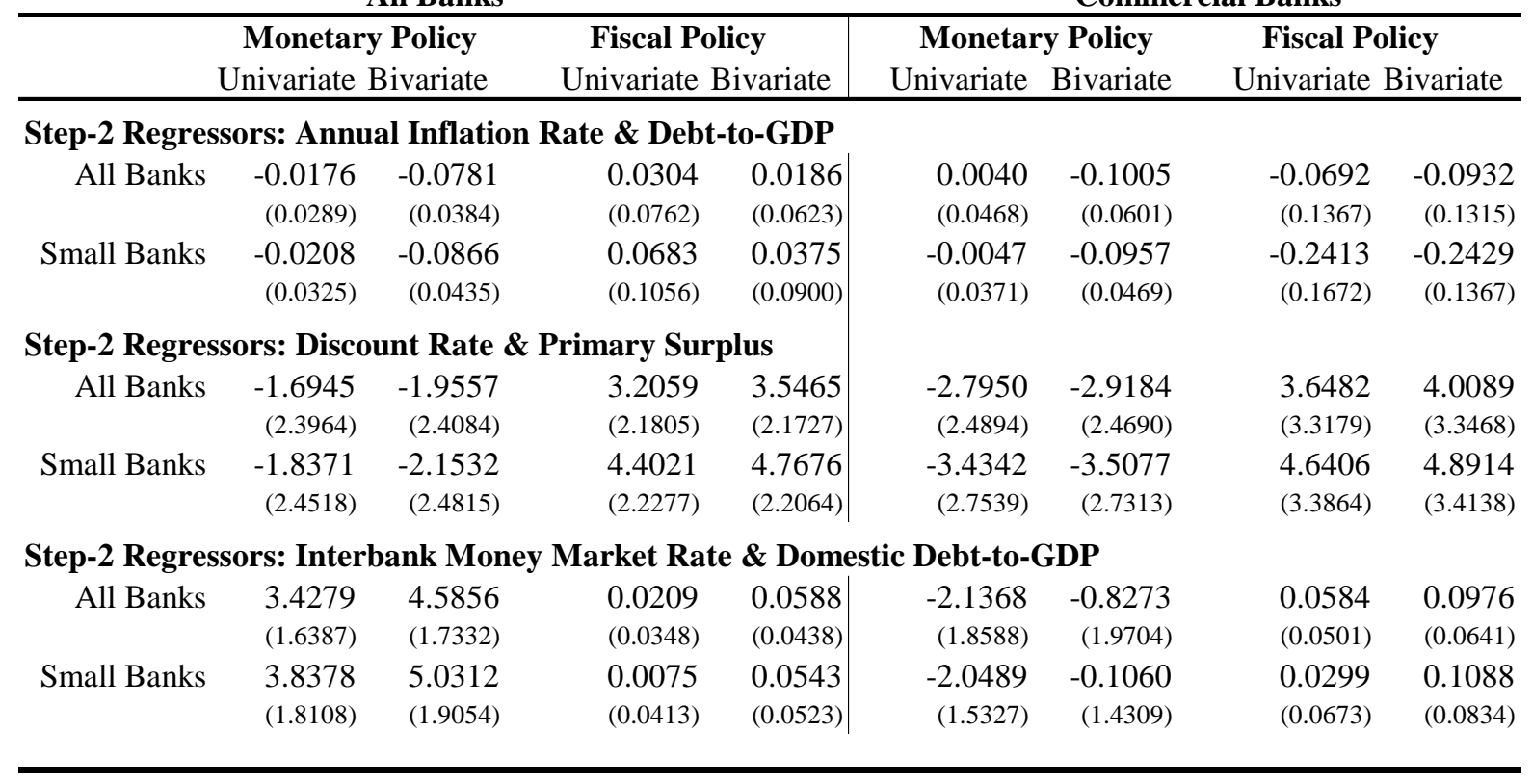

Note: Standard errors are in parantheses.

As displayed in Table 5, the negative monetary coefficients are obtained only for the inflation and discount rates. Conversely, we obtain a positive and significant coefficient estimate for interbank money market rate for all banks operating in Turkey. These results indicate two important observations. First, monetary policy variables are better measured through the inflation and discount rates, which reflect the supply-side impact of monetary 
policy on bank lending. On the other hand, interbank money market rate works as a financial deepening variable: a decline in interbank rate corresponds to an increase in the importance of liquidity in bank loan creation, possibly through the use of interbank lending. Second, the insignificance of the interbank money market coefficient estimate for commercial banks show that the impact of this variable is stronger on development and investment banks operating in Turkey.

Fiscal policy variables in Table 5 do not provide robust results. The only negative and significant coefficient estimates are obtained for gross debt-to-GDP ratio for commercial banks with size also being a factor for the significance of results. This finding indicates that a decline in public debt frees up resources and increases credit growth further for small commercial banks.

Last, estimation results are calculated first for all banks in the group and then for small banks. Small banks are the ones which are in the lower 95 percentile of the size -measured by total assets of a bank- distribution of the total banking sector for a given year. ${ }^{17}$ The results in Table 5 show that the impacts of monetary and fiscal policy are more pronounced for small banks. The sums of the coefficient estimates of policy variables are more negative for small banks and they have a higher significance level. As discussed earlier, this shows that small banks are more constrained in their access to financial markets during tighter monetary policy and in their ability to reaching a broader customer group (geographically and/or on borrowers engaged in certain types of economic activity) in case of a switch in their business focus, i.e., a switch from financing government debt to lending to the private sector. Therefore, monetary and fiscal policies affect small banks more than they do the larger ones.

\section{B. Impact of Monetary and Fiscal Policies on Credit Supply: Currency Denomination of Loans}

In this section, we apply the two stage methodology separately for loans extended in domestic and foreign currencies. The purpose is to observe whether there are any significant differences in the impact of monetary and fiscal policy on credit growth with respect to the currency denomination of loans. The results are reported in Table 6, which has the same layout as that of Table 5. Panel A in Table 6 shows the estimation results for loans denominated in the domestic currency while Panel B presents the results for loans denominated in foreign currencies.

The results in Table 6 show that the monetary policy is much stronger for loans extended in domestic currency: both the magnitude and significance level of coefficient estimates of monetary policy variables are larger for loans extended in domestic currency. This result

\footnotetext{
${ }^{17}$ Even though the rankings for bank size are performed for each quarter in the sample, in Turkey, three banks are dominantly larger than the rest for every given time period. These are Türkiye Cumhuriyeti Ziraat Bankası, a state-owned bank, Akbank T.A.Ş. and Türkiye İş Bankası A.Ş., where the latter two are privately owned domestic banks.
} 
indicates that a tightening of monetary policy restricts domestic-currency credit growth in banks, and this constraint gets stronger for less liquid and smaller banks. On the other hand, for loans extended in foreign currencies monetary policy, measured by inflation and discount rates, the analysis does not yield significant results. This shows that monetary policy is ineffective in limiting the supply of foreign credit, giving little hope for monetary authority to controlling private sector borrowing in foreign currencies.

Interbank money market lending rate, on the other hand, works in the same direction for loans extended in domestic and loans extended in foreign currencies. As aforementioned in the previous section, this variable indicates more of financial deepening rather than monetary tightening, and therefore, it is not surprising to see a similar impact of this variable for loans denominated in both domestic and foreign currencies. When financial markets lose depth in the sense that interbank funding becomes less accessible, banks find it harder to supply credit to the private sector and this is especially the case for less liquid and smaller banks.

As shown in Table 6, fiscal policy is significant only for loans extended in domestic currency, and it yields negative and significant coefficient estimates for fiscal policy variables measured in gross debt-to-GDP and primary surplus ratios. These results have two important indications. First, government's financing need reduces the bank supply of loan available to the private sector; and fiscal discipline increases this supply of credit. Second, supply of loans to the private sector denominated in foreign currency is independent of banks' government debt financing, indicating that the spread between domestic and foreign interest rates is probably the main supply side factor for these types of loans.

Last, it is also worth noting that univariate estimation approach does not reveal many of these effects while the bivariate approach, by taking the situation of the economy into account, unveils the impact of policy stance on banks' lending.

\section{Impact of Monetary and Fiscal Policies on Credit Supply: Maturity of Loans}

In this section, we study the impact of monetary and fiscal policy on loan supply with respect to the maturity structure of bank loans. The results are reported in Table 7, with a similar layout as that of Table 6. Panel A of Table 7 presents the results for loans extended in shortterm maturity and Panel B of Table 7 shows the results for medium-to-long-term loans.

The results show that the impact of monetary policy, through inflation rate, on longer term loans is in line with our hypothesis: monetary tightening reduces the supply of longer term loans. On the other hand, significant and positive coefficients emerge for short-term loans extended by commercial banks. These results indicate that as monetary policy tightens, it leads banks to extend less of long-term and more of short-term loans. Notice also that these results are in line with inflation expectations.

Fiscal policy seems not to affect the long-term loan supply of banks, but the short-term loan supply. The results indeed deliver, positive and significant coefficient estimates for fiscal policy variables measured in terms of the ratios of primary surplus and domestic debt-to- 
Table 6. Sum of Coefficients on Monetary and Fiscal Policy Indicators with respect to Currency Decomposition of Credit

\begin{tabular}{|c|c|c|c|c|c|c|c|c|}
\hline \multicolumn{9}{|c|}{ PANEL A: Domestic Currency } \\
\hline \multicolumn{5}{|c|}{ All Banks } & \multicolumn{4}{|c|}{ Commercial Banks } \\
\hline & \multicolumn{2}{|c|}{ Monetary Policy } & \multicolumn{2}{|c|}{ Fiscal Policy } & \multicolumn{2}{|c|}{ Monetary Policy } & \multicolumn{2}{|c|}{ Fiscal Policy } \\
\hline & Univariate & Bivariate & Univariate & Bivariate & Univariate & Bivariate & Univariate & Bivariate \\
\hline \multicolumn{9}{|c|}{ Step-2 Regressors: Annual Inflation Rate \& Debt-to-GDP } \\
\hline All Banks & $\begin{array}{r}-0.0263 \\
(0.0181)\end{array}$ & $\begin{array}{r}-0.0883 \\
(0.0184)\end{array}$ & $\begin{array}{r}-0.0739 \\
(0.0894)\end{array}$ & $\begin{array}{r}-0.0787 \\
(0.0969)\end{array}$ & $\begin{array}{r}-0.0404 \\
(0.0760)\end{array}$ & $\begin{array}{r}-0.2004 \\
(0.0994)\end{array}$ & $\begin{array}{r}-0.3931 \\
(0.2444)\end{array}$ & $\begin{array}{r}-0.5981 \\
(0.2515)\end{array}$ \\
\hline Small Banks & $\begin{array}{r}-0.0246 \\
(0.0188)\end{array}$ & $\begin{array}{r}-0.0901 \\
(0.0188)\end{array}$ & $\begin{array}{r}-0.0737 \\
(0.0824)\end{array}$ & $\begin{array}{r}-0.0754 \\
(0.0878)\end{array}$ & $\begin{array}{r}-0.0405 \\
(0.0747)\end{array}$ & $\begin{array}{r}-0.2260 \\
(0.0941)\end{array}$ & $\begin{array}{r}-0.4663 \\
(0.2311)\end{array}$ & $\begin{array}{r}-0.6408 \\
(0.2430)\end{array}$ \\
\hline \multicolumn{9}{|c|}{ Step-2 Regressors: Discount Rate \& Primary Surplus } \\
\hline All Banks & $\begin{array}{l}4.3968 \\
(3.1867)\end{array}$ & $\begin{array}{l}4.3092 \\
(3.1361)\end{array}$ & $\begin{array}{r}-6.8474 \\
(2.7502)\end{array}$ & $\begin{array}{r}-6.7833 \\
(2.7490)\end{array}$ & $\begin{array}{r}-12.8294 \\
(11.5013)\end{array}$ & $\begin{array}{r}-11.4055 \\
(11.4000)\end{array}$ & $\begin{array}{r}-6.8132 \\
(8.2102)\end{array}$ & $\begin{array}{r}-6.7478 \\
(7.7158)\end{array}$ \\
\hline Small Banks & $\begin{array}{l}5.6371 \\
(3.0917)\end{array}$ & $\begin{array}{l}5.5686 \\
(3.0791)\end{array}$ & $\begin{array}{r}-2.6265 \\
(2.4110)\end{array}$ & $\begin{array}{r}-2.5624 \\
(2.4035)\end{array}$ & $\begin{array}{r}-10.2857 \\
(11.0009)\end{array}$ & $\begin{array}{l}-9.0774 \\
(10.8747)\end{array}$ & $\begin{array}{r}-5.7961 \\
(7.9874)\end{array}$ & $\begin{array}{r}-5.5783 \\
(7.7959)\end{array}$ \\
\hline \multicolumn{9}{|c|}{ Step-2 Regressors: Interbank Money Market Rate \& Domestic Debt-to-GDP } \\
\hline All Banks & $\begin{array}{l}2.4824 \\
(0.9760)\end{array}$ & $\begin{array}{l}3.3702 \\
(1.0217)\end{array}$ & $\begin{array}{l}0.0570 \\
(0.0404)\end{array}$ & $\begin{array}{l}0.0305 \\
(0.0479)\end{array}$ & $\begin{array}{r}-2.8399 \\
(3.1039)\end{array}$ & $\begin{array}{r}-0.9593 \\
(3.4263)\end{array}$ & $\begin{array}{l}0.0025 \\
(0.1079)\end{array}$ & $\begin{array}{r}-0.1323 \\
(0.1224)\end{array}$ \\
\hline Small Banks & $\begin{array}{l}2.6312 \\
(1.0253)\end{array}$ & $\begin{array}{l}3.6458 \\
(1.0385)\end{array}$ & $\begin{array}{l}0.0278 \\
(0.0337)\end{array}$ & $\begin{array}{l}0.0071 \\
(0.0401)\end{array}$ & $\begin{array}{r}-2.8296 \\
(3.1574)\end{array}$ & $\begin{array}{r}-0.0636 \\
(3.3993)\end{array}$ & $\begin{array}{l}0.0393 \\
(0.1105)\end{array}$ & $\begin{array}{r}-0.0282 \\
(0.1320)\end{array}$ \\
\hline
\end{tabular}

PANEL B: Foreign Currency

All Banks

Commercial Banks

\begin{tabular}{|c|c|c|c|c|c|c|c|c|}
\hline \multirow{2}{*}{\multicolumn{3}{|c|}{$\begin{array}{c}\text { Monetary Policy } \\
\text { Univariate Bivariate }\end{array}$}} & \multirow{2}{*}{\multicolumn{2}{|c|}{$\begin{array}{c}\text { Fiscal Policy } \\
\text { Univariate Bivariate } \\
\end{array}$}} & \multicolumn{2}{|c|}{ Monetary Policy } & \multirow{2}{*}{\multicolumn{2}{|c|}{$\begin{array}{c}\text { Fiscal Policy } \\
\text { Univariate Bivariate } \\
\end{array}$}} \\
\hline & & & & & Univariate & Bivariate & & \\
\hline \multicolumn{9}{|c|}{ Step-2 Regressors: Annual Inflation Rate \& Debt-to-GDP } \\
\hline All Banks & $\begin{array}{l}0.0304 \\
(0.0155)\end{array}$ & $\begin{array}{l}0.0008 \\
(0.0208)\end{array}$ & $\begin{array}{l}0.0882 \\
(0.1103)\end{array}$ & $\begin{array}{l}0.0995 \\
(0.0998)\end{array}$ & $\begin{array}{l}0.0432 \\
(0.0329)\end{array}$ & $\begin{array}{r}-0.0128 \\
(0.0451)\end{array}$ & $\begin{array}{l}0.1456 \\
(0.1590)\end{array}$ & $\begin{array}{l}0.1337 \\
(0.1566)\end{array}$ \\
\hline Small Banks & $\begin{array}{l}0.0282 \\
(0.0168)\end{array}$ & $\begin{array}{r}-0.0001 \\
(0.0228)\end{array}$ & $\begin{array}{r}-0.0136 \\
(0.1343)\end{array}$ & $\begin{array}{l}0.0080 \\
(0.1188)\end{array}$ & $\begin{array}{l}0.0441 \\
(0.0335)\end{array}$ & $\begin{array}{r}-0.0070 \\
(0.0464)\end{array}$ & $\begin{array}{l}0.1256 \\
(0.1370)\end{array}$ & $\begin{array}{l}0.1236 \\
(0.1280)\end{array}$ \\
\hline \multicolumn{9}{|c|}{ Step-2 Regressors: Discount Rate \& Primary Surplus } \\
\hline All Banks & $\begin{array}{l}2.2522 \\
(3.3706)\end{array}$ & $\begin{array}{l}2.6488 \\
(2.8256)\end{array}$ & $\begin{array}{l}1.1031 \\
(3.0477)\end{array}$ & $\begin{array}{l}0.8794 \\
(3.0401)\end{array}$ & $\begin{array}{l}3.5972 \\
(5.8969)\end{array}$ & $\begin{array}{l}4.1890 \\
(5.2958)\end{array}$ & $\begin{array}{l}1.2779 \\
(4.1262)\end{array}$ & $\begin{array}{l}1.4619 \\
(4.1476)\end{array}$ \\
\hline Small Banks & $\begin{array}{l}4.1367 \\
(3.5926)\end{array}$ & $\begin{array}{l}4.6339 \\
(2.9956)\end{array}$ & $\begin{array}{r}-0.0213 \\
(3.6592)\end{array}$ & $\begin{array}{r}-0.5140 \\
(3.5960)\end{array}$ & $\begin{array}{l}3.6163 \\
(5.9943)\end{array}$ & $\begin{array}{l}4.1017 \\
(5.1519)\end{array}$ & $\begin{array}{l}1.5154 \\
(3.8482)\end{array}$ & $\begin{array}{l}1.6106 \\
(3.8275)\end{array}$ \\
\hline \multicolumn{9}{|c|}{ Step-2 Regressors: Interbank Money Market Rate \& Domestic Debt-to-GDP } \\
\hline All Banks & $\begin{array}{l}1.2495 \\
(1.1112)\end{array}$ & $\begin{array}{l}2.8774 \\
(0.9815)\end{array}$ & $\begin{array}{l}0.0336 \\
(0.0743)\end{array}$ & $\begin{array}{l}0.0915 \\
(0.0897)\end{array}$ & $\begin{array}{r}-1.3836 \\
(1.6804)\end{array}$ & $\begin{array}{l}0.4536 \\
(1.6377)\end{array}$ & $\begin{array}{l}0.1400 \\
(0.1050)\end{array}$ & $\begin{array}{l}0.1480 \\
(0.1305)\end{array}$ \\
\hline Small Banks & $\begin{array}{l}1.6366 \\
(1.2223)\end{array}$ & $\begin{array}{l}3.5991 \\
(1.0283)\end{array}$ & $\begin{array}{l}0.0507 \\
(0.0880)\end{array}$ & $\begin{array}{l}0.1477 \\
(0.1029)\end{array}$ & $\begin{array}{r}-1.6358 \\
(1.6986)\end{array}$ & $\begin{array}{l}0.4894 \\
(1.5972)\end{array}$ & $\begin{array}{l}0.0821 \\
(0.0962)\end{array}$ & $\begin{array}{l}0.1219 \\
(0.1178)\end{array}$ \\
\hline
\end{tabular}

Note: Standard errors are in parantheses.

GDP. This may indicate that the retail banking focus for a bank is less important in extending loans of shorter maturity; and indeed many banks that do not have a retail banking business focus may prefer to extend shorter term maturity loans, probably because this are less prone to mistakes in risk management at which these banks might have a disadvantage, when government reduces its domestic debt financing need by banks. 


\section{Impact of Monetary and Fiscal Policies on Credit Supply: Bank Ownership}

Finally, we apply the two-step methodology to measure the size of fiscal and monetary policies on the loan supply of all foreign banks operating in Turkey. The results from this section are reported in Table 8 , and it shows the results obtained by using liquidity measure 2 in step-one estimations. The table is divided into three panels: in Panel A, we present the results for total loan supply of foreign banks; in Panel $\mathrm{B}$, for loans extended in domestic currency; and in Panel C, for loans extended in foreign currencies. Unfortunately, due to data limitations, we cannot employ the analysis with respect to the maturity structure of loans for foreign banks operating in Turkey.

Looking at Panel A, one can see that the monetary policy has the expected negative sign for foreign banks, however, with low significance levels. Furthermore, looking at Panel C, the negative coefficient estimates seem to be driven by the foreign-currency-denominated loans. The coefficient estimate for inflation rate is significant and negative for the foreign currency loan supply of foreign banks. Comparing these results to the ones reported in Table 6, we see that this is not the case in the regressions conducted using the whole sample. This difference is likely to stem from the fact that these banks and these types of loans are the ones that tend to be more constrained in their access to the external financing sources because of their size and more specialized in the way they work with particular borrowers and/or have a more advanced management system through implementation of techniques from their parent banks. Because of these characteristics, monetary policy might have a more pronounced impact for foreign-currency-denominated loans of foreign banks.

Last, results in Table 8 give little evidence of fiscal policy on the growth of foreign banks' credit supply, either in total or in terms of currency denomination of the loans. This may support the view that foreign banks enter to the Turkish banking sector because of higher economic growth prospects and lower competition, compared to the circumstances in their home markets, rather than solely investing in government securities to finance public debt.

\section{Conclusion}

We study the impact of monetary and fiscal policies on the growth of credit to the private sector in Turkey. By gathering detailed bank-level data from the last quarter of 2002 to the first of 2008, we are able to use the cross-sectional variation in banks liquidity positions and business models to disentangle the supply- and demand-side effects. We show that the liquidity-constrained banks have sharper decline in lending during contractionary monetary policies and that crowding-out effect disappears more for banks with a retail-banking focus already in place when the government adopts fiscal discipline. The empirical findings suggest that bank lending channel of monetary policy and fiscal policy transmission is particularly important for credit denominated in domestic currency. Furthermore, a contraction in any of these policies leads banks to extend more of short-term credit as the importance of liquidity constraints and retail-banking focus diminishes for loans at shortterm maturity. Lastly, the impacts of monetary and fiscal policies are limited for loans extended in foreign currencies and for foreign banks. 
Table 7. Sum of Coefficients on Monetary and Fiscal Policy Indicators with respect to Maturity of Credit

\begin{tabular}{|c|c|c|c|c|c|c|c|c|}
\hline \multicolumn{9}{|c|}{ PANEL A: Short-Term Loan } \\
\hline \multicolumn{5}{|c|}{ All Banks } & \multicolumn{4}{|c|}{ Commercial Banks } \\
\hline & \multicolumn{2}{|c|}{ Monetary Policy } & \multicolumn{2}{|c|}{ Fiscal Policy } & \multicolumn{2}{|c|}{ Monetary Policy } & \multicolumn{2}{|c|}{ Fiscal Policy } \\
\hline & Univariate & Bivariate & Univariate & Bivariate & Univariate & Bivariate & Univariate & Bivariate \\
\hline \multicolumn{9}{|c|}{ Step-2 Regressors: Annual Inflation Rate \& Debt-to-GDP } \\
\hline All Banks & $\begin{array}{l}0.0064 \\
(0.0350)\end{array}$ & $\begin{array}{r}-0.0317 \\
(0.0461)\end{array}$ & $\begin{array}{r}-0.1590 \\
(0.3912)\end{array}$ & $\begin{array}{r}-0.0980 \\
(0.3962)\end{array}$ & $\begin{array}{l}0.0610 \\
(0.0372)\end{array}$ & $\begin{array}{l}0.0425 \\
(0.0484)\end{array}$ & $\begin{array}{l}0.6257 \\
(0.5871)\end{array}$ & $\begin{array}{l}0.8172 \\
(0.5973)\end{array}$ \\
\hline Small Banks & $\begin{array}{l}0.0036 \\
(0.0374)\end{array}$ & $\begin{array}{r}-0.0349 \\
(0.0491)\end{array}$ & $\begin{array}{r}-0.2000 \\
(0.4009)\end{array}$ & $\begin{array}{r}-0.1689 \\
(0.4143)\end{array}$ & $\begin{array}{l}0.0707 \\
(0.0321)\end{array}$ & $\begin{array}{l}0.0617 \\
(0.0432)\end{array}$ & $\begin{array}{l}0.3603 \\
(0.4293)\end{array}$ & $\begin{array}{l}0.2614 \\
(0.4521)\end{array}$ \\
\hline \multicolumn{9}{|c|}{ Step-2 Regressors: Discount Rate \& Primary Surplus } \\
\hline All Banks & $\begin{array}{l}5.3621 \\
(9.1243)\end{array}$ & $\begin{array}{l}14.1842 \\
(10.8685)\end{array}$ & $\begin{array}{l}18.9393 \\
(10.4449)\end{array}$ & $\begin{array}{l}16.0605 \\
(12.6179)\end{array}$ & $\begin{array}{r}13.0293 \\
(9.1464)\end{array}$ & $\begin{array}{l}20.3004 \\
(10.2376)\end{array}$ & $\begin{array}{r}3.7029 \\
(12.9596)\end{array}$ & $\begin{array}{l}-5.0136 \\
(15.6451)\end{array}$ \\
\hline Small Banks & $\begin{array}{l}5.0126 \\
(9.5579)\end{array}$ & $\begin{array}{l}13.1177 \\
(11.3827)\end{array}$ & $\begin{array}{l}20.6734 \\
(11.1905)\end{array}$ & $\begin{array}{r}20.4522 \\
(13.8240)\end{array}$ & $\begin{array}{r}20.3347 \\
(8.5567)\end{array}$ & $\begin{array}{r}34.2759 \\
(9.1272)\end{array}$ & $\begin{array}{r}3.4256 \\
(10.1551)\end{array}$ & $\begin{array}{l}14.5620 \\
(11.6725)\end{array}$ \\
\hline \multicolumn{9}{|c|}{ Step-2 Regressors: Interbank Money Market Rate \& Domestic Debt-to-GDP } \\
\hline All Banks & $\begin{array}{l}2.5859 \\
(8.9413)\end{array}$ & $\begin{array}{l}4.6269 \\
(9.8825)\end{array}$ & $\begin{array}{l}0.3877 \\
(0.1342)\end{array}$ & $\begin{array}{l}0.3296 \\
(0.1351)\end{array}$ & $\begin{array}{r}-5.0634 \\
(9.7407)\end{array}$ & $\begin{array}{r}2.0807 \\
(10.2145)\end{array}$ & $\begin{array}{l}0.4204 \\
(0.1432)\end{array}$ & $\begin{array}{l}0.4038 \\
(0.1527)\end{array}$ \\
\hline Small Banks & $\begin{array}{r}-1.4387 \\
(9.2314)\end{array}$ & $\begin{array}{r}1.2046 \\
(10.1732)\end{array}$ & $\begin{array}{l}0.3638 \\
(0.1367)\end{array}$ & $\begin{array}{l}0.3331 \\
(0.1433)\end{array}$ & $\begin{array}{r}-1.4976 \\
(8.3456)\end{array}$ & $\begin{array}{r}10.8167 \\
(8.0992)\end{array}$ & $\begin{array}{l}0.4842 \\
(0.1192)\end{array}$ & $\begin{array}{l}0.5470 \\
(0.1140)\end{array}$ \\
\hline
\end{tabular}

PANEL B: Medium-to-Long-Term Loan

\begin{tabular}{|c|c|c|c|c|c|c|c|c|}
\hline \multicolumn{5}{|c|}{ All Banks } & \multicolumn{4}{|c|}{ Commercial Banks } \\
\hline & \multirow{2}{*}{\multicolumn{2}{|c|}{$\begin{array}{c}\text { Monetary Policy } \\
\text { Univariate Bivariate }\end{array}$}} & \multirow{2}{*}{\multicolumn{2}{|c|}{$\begin{array}{c}\text { Fiscal Policy } \\
\text { Univariate Bivariate }\end{array}$}} & \multicolumn{2}{|c|}{ Monetary Policy } & \multirow{2}{*}{\multicolumn{2}{|c|}{$\begin{array}{c}\text { Fiscal Policy } \\
\text { Univariate Bivariate }\end{array}$}} \\
\hline & & & & & Univariate & Bivariate & & \\
\hline \multicolumn{9}{|c|}{ Step-2 Regressors: Annual Inflation Rate \& Debt-to-GDP } \\
\hline All Banks & $\begin{array}{l}0.0000 \\
(0.0596)\end{array}$ & $\begin{array}{r}-0.1491 \\
(0.0572)\end{array}$ & $\begin{array}{r}-0.1877 \\
(0.4190)\end{array}$ & $\begin{array}{r}-0.2024 \\
(0.3958)\end{array}$ & $\begin{array}{l}0.0413 \\
(0.0628)\end{array}$ & $\begin{array}{r}-0.1057 \\
(0.0625)\end{array}$ & $\begin{array}{r}-0.0687 \\
(0.4002)\end{array}$ & $\begin{array}{r}-0.0712 \\
(0.3994)\end{array}$ \\
\hline Small Banks & $\begin{array}{l}0.0112 \\
(0.0649)\end{array}$ & $\begin{array}{r}-0.1570 \\
(0.0585)\end{array}$ & $\begin{array}{r}-0.4327 \\
(0.5607)\end{array}$ & $\begin{array}{r}-0.4168 \\
(0.5260)\end{array}$ & $\begin{array}{l}0.0275 \\
(0.0663)\end{array}$ & $\begin{array}{r}-0.1316 \\
(0.0623)\end{array}$ & $\begin{array}{r}-0.3854 \\
(0.5907)\end{array}$ & $\begin{array}{r}-0.3378 \\
(0.5779)\end{array}$ \\
\hline \multicolumn{9}{|c|}{ Step-2 Regressors: Discount Rate \& Primary Surplus } \\
\hline All Banks & $\begin{array}{l}3.8769 \\
(7.7600)\end{array}$ & $\begin{array}{r}-3.5968 \\
(8.8153)\end{array}$ & $\begin{array}{r}3.5290 \\
(24.4988)\end{array}$ & $\begin{array}{r}3.9187 \\
(25.0128)\end{array}$ & $\begin{array}{l}10.2463 \\
(10.0294)\end{array}$ & $\begin{array}{r}5.0546 \\
(11.6848)\end{array}$ & $\begin{array}{l}23.8750 \\
(27.4942)\end{array}$ & $\begin{array}{l}14.6952 \\
(26.7090)\end{array}$ \\
\hline Small Banks & $\begin{array}{l}7.2371 \\
(8.5660)\end{array}$ & $\begin{array}{r}-4.0581 \\
(9.0963)\end{array}$ & $\begin{array}{r}3.2624 \\
(28.8478)\end{array}$ & $\begin{array}{r}4.3326 \\
(29.3730)\end{array}$ & $\begin{array}{r}6.0063 \\
(10.2945)\end{array}$ & $\begin{array}{l}-1.0116 \\
(11.6498)\end{array}$ & $\begin{array}{l}27.6127 \\
(31.9106)\end{array}$ & $\begin{array}{l}18.7191 \\
(32.1434)\end{array}$ \\
\hline \multicolumn{9}{|c|}{ Step-2 Regressors: Interbank Money Market Rate \& Domestic Debt-to-GDP } \\
\hline All Banks & $\begin{array}{l}28.8100 \\
(12.3187)\end{array}$ & $\begin{array}{l}19.9682 \\
(12.5697)\end{array}$ & $\begin{array}{r}-0.1574 \\
(0.1713)\end{array}$ & $\begin{array}{r}-0.1564 \\
(0.1768)\end{array}$ & $\begin{array}{l}31.6550 \\
(13.8612)\end{array}$ & $\begin{array}{c}24.9555 \\
(15.0470)\end{array}$ & $\begin{array}{r}-0.0175 \\
(0.1570)\end{array}$ & $\begin{array}{r}-0.0575 \\
(0.1603)\end{array}$ \\
\hline Small Banks & $\begin{array}{l}33.0984 \\
(13.6553)\end{array}$ & $\begin{array}{l}22.6041 \\
(13.5461)\end{array}$ & $\begin{array}{r}-0.2121 \\
(0.2029)\end{array}$ & $\begin{array}{r}-0.1799 \\
(0.2059)\end{array}$ & $\begin{array}{l}30.5831 \\
(14.3363)\end{array}$ & $\begin{array}{l}23.5563 \\
(15.3854)\end{array}$ & $\begin{array}{r}-0.1503 \\
(0.1858)\end{array}$ & $\begin{array}{r}-0.1220 \\
(0.1921)\end{array}$ \\
\hline
\end{tabular}

Note: Standard errors are in parantheses. 
Table 8. Sum of Coefficients on Monetary and Fiscal Policy Indicators for Foreign Banks

\begin{tabular}{lcccc}
\hline \multicolumn{4}{l}{ PANEL A: Total Loans } & \\
\hline \multicolumn{4}{c}{ Monetary Policy } & \multicolumn{2}{c}{ Fiscal Policy } \\
Univariate & Bivariate & Univariate & Bivariate \\
\hline Step-2: Annual Inflation Rate \& Debt-to-GDP & & \\
-0.0838 & -0.1762 & -0.3250 & -0.3129 \\
$(0.1420)$ & $(0.2005)$ & $(0.6644)$ & $(0.6553)$ \\
Step-2: Discount Rate \& Primary Surplus & & \\
-0.0095 & -0.0732 & 0.6412 & 0.6648 \\
$(0.5861)$ & $(0.6008)$ & $(0.5083)$ & $(0.4842)$
\end{tabular}

Step-2: Interbank M. M. Rate \& Domestic Debt-to-GDP

$\begin{array}{llrl}0.1288 & 0.1341 & -0.0023 & 0.0385 \\ (0.0694) & (0.0781) & (0.0331) & (0.0420)\end{array}$

PANEL B: Domestic Currency Loans

\begin{tabular}{|c|c|c|c|}
\hline \multicolumn{2}{|c|}{$\begin{array}{c}\text { Monetary Policy } \\
\text { Univariate Bivariate }\end{array}$} & \multicolumn{2}{|c|}{$\begin{array}{c}\text { Fiscal Policy } \\
\text { Univariate Bivariate }\end{array}$} \\
\hline \multicolumn{4}{|c|}{ Step-2: Annual Inflation Rate \& Debt-to-GDP } \\
\hline 0.2515 & 0.4306 & 1.0849 & 1.3507 \\
\hline$(0.2663)$ & $(0.3849)$ & $(0.8935)$ & $(0.8436)$ \\
\hline \multicolumn{4}{|c|}{ Step-2: Discount Rate \& Primary Surplus } \\
\hline-2.7915 & -2.5747 & -18.5211 & -18.6743 \\
\hline$(4.6482)$ & $(4.6229)$ & $(22.9380)$ & $(18.0884)$ \\
\hline \multicolumn{4}{|c|}{ Step-2: Interbank M. M. Rate \& Domestic Debt-to-GDP } \\
\hline-0.7473 & -1.9271 & 0.0007 & -0.6077 \\
\hline$(1.4534)$ & $(1.5254)$ & $(0.3728)$ & $(0.3952)$ \\
\hline \multicolumn{4}{|c|}{ PANEL C: Foreign Currency Loans } \\
\hline \multicolumn{2}{|c|}{ Monetary Policy } & \multicolumn{2}{|c|}{ Fiscal Policy } \\
\hline \multicolumn{2}{|c|}{ Univariate Bivariate } & \multicolumn{2}{|c|}{ Univariate Bivariate } \\
\hline \multicolumn{4}{|c|}{ Step-2: Annual Inflation Rate \& Debt-to-GDP } \\
\hline-0.3294 & -0.8062 & -0.5836 & -0.6250 \\
\hline$(0.2147)$ & $(0.2803)$ & $(0.4498)$ & $(0.4247)$ \\
\hline \multicolumn{4}{|c|}{ Step-2: Discount Rate \& Primary Surplus } \\
\hline-1.3933 & -1.0553 & -12.4968 & -13.9599 \\
\hline$(3.8600)$ & $(3.8602)$ & $(10.1205)$ & $(9.4444)$ \\
\hline \multicolumn{4}{|c|}{ Step-2: Interbank M. M. Rate \& Domestic Debt-to-GDP } \\
\hline 0.3708 & 1.1679 & 0.1729 & -0.0793 \\
\hline$(1.2374)$ & $(1.3470)$ & $(0.2189)$ & $(0.2456)$ \\
\hline
\end{tabular}

Note: Standard errors are in parantheses. 


\section{Appendix}

\section{A. Definition of Variables}

We use three monetary policy variables. The first variable is the annual inflation rate as itself, such that declines in this variable show monetary contraction. The other two variables are discount rate policy variable, $1 /$ discount $_{t}$, and the interbank policy variable,

$1 /$ int erbank $k_{t}$. We use the inverse function, so that a decline in the discount or interbank policy variables indicates monetary tightening.

Similarly, we use three fiscal policy variables. The total debt policy variable is TotalDebt $_{t} / G D P_{t}$, domestic debt policy variable is DomesticDebt $t_{t} / G D P_{t}$, and the primary policy variable is calculated as $G D P_{t}$ / PrimarySurplus $s_{t}$, so that a decrease in any of these variables indicates fiscal tightening. As to be explained later in Appendix B, the fiscal policy variables are calculated from the quarterly-smoothed macroeconomic variables.

Last, the retail rank measure, $R_{i t}$, is calculated as $R_{i t}=\frac{(\text { Loan } / \text { TotalAsset })_{i t}}{\frac{1}{N_{t}} \sum_{i}^{N_{t}}\left(\frac{\text { Loan }}{\text { TotalAsset }}\right)_{i t}}$.

\section{B. Quarterly Smoothing of Fiscal Policy Variables}

One problem that arises with the study of macroeconomic data is that many variables show seasonal fluctuations. In our data set, we observe this seasonal variation in the quarterly observed values of GDP. ${ }^{18}$ As our fiscal policy variables are composed as a percentage of quarterly observed values of GDP, these seasonal fluctuations may potentially bias our results. Figure 5 plots the fiscal variables over time, and it clearly shows that all of our fiscal policy variables demonstrate seasonal fluctuations.

In order to eliminate seasonal fluctuations from the fiscal variables, we apply the Lowess smoothing methodology. For each fiscal policy variable, $x_{i}$, we generate a quarterly smoothed variable, $x_{i}^{s}$, by smoothing it over each quarter, $t_{i}$, for $i=1 \ldots T$. The subsets used in calculating $x_{i}^{s}$ are indices such that:

where $\quad k=\left\lfloor\frac{\text { T.bwidth }-0.5}{2}\right\rfloor$.

$$
\begin{aligned}
& i_{-}=\max (1, i-k) \\
& i_{+}=\min (i+k, T)
\end{aligned}
$$

\footnotetext{
${ }^{18}$ Since we use annual inflation rate in our analysis, rather than quarterly inflation rate, this variable does not show seasonality.
} 
Figure 5. Observed and Quarterly-Smoothed Fiscal Variables
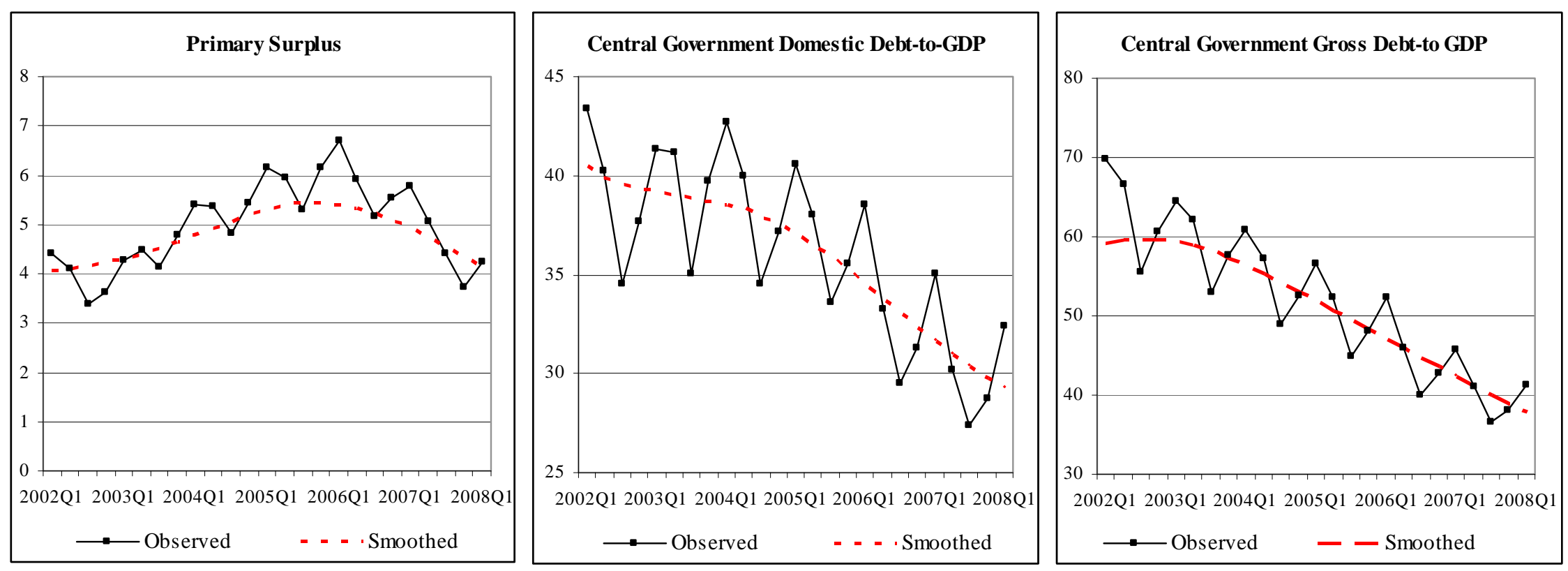
Then the quarterly-smoothed value of fiscal variable $x_{i}^{s}$ is the weighted regression of $x_{i}$ on t, where the weights of each observation between $j=i_{-}, \ldots, i_{+}$are $w_{j}=\left[1-\left(\frac{\left|t_{j}-t_{i}\right|}{\Delta}\right)^{3}\right]^{3}$, for $\Delta=1.0001 \max \left(t_{i+}-t_{i}, t_{i}-t_{i-}\right)$.

\section{Coefficient Estimates from Step-1 Regressions}

Table 9 below presents the sums of time-variant coefficient estimates of liquidity and retail ranking variables from the step-one regression expressed in equation (1), in the model section of this paper. This table shows the sum of the liquidity coefficient estimates for both measures of liquidity. As discussed in the paper, liquidity measure 1 is a broad measure covering also the bank's investments in government debt securities. Therefore, the coefficient estimates for liquidity measure 1 do not only yield positive sums. On the other hand, the sums of the coefficient estimates for liquidity measure 2 indicate the expected positive sign except a few exceptions. Similarly, the sum of coefficient estimates for retail banking focus variable are also positive.

Table 9. Sum of Liquidity and Retail Rank Coefficients Estimated in Step-1

\begin{tabular}{|c|c|c|c|c|c|c|}
\hline \multicolumn{7}{|c|}{ Sum of Liquidity Coefficients } \\
\hline & \multirow{2}{*}{$\begin{array}{c}\text { Liquidity-1 } \\
\text { Total }\end{array}$} & \multicolumn{5}{|c|}{$\begin{array}{ll}\text { Liquidity-2 } & \end{array}$} \\
\hline & & Total & Domestic & Foreign & Short-Term & M-to-L Term \\
\hline All & -0.1981 & 1.4910 & -1.1011 & 3.5944 & 0.8710 & 1.7971 \\
\hline Small & -1.0266 & 1.3046 & -0.9427 & 3.7836 & 1.5547 & 1.5768 \\
\hline Commercial & 1.0103 & 6.1877 & 4.1570 & 5.0749 & 1.2323 & 0.1115 \\
\hline Small-Commercial & 1.0771 & 2.0396 & 3.9302 & 4.7570 & 1.1624 & -0.3522 \\
\hline Foreign & & 0.1508 & -26.1242 & 10.3439 & & \\
\hline \multicolumn{7}{|c|}{ Sum of Retail Rank Coefficients } \\
\hline & Liquidity-1 & & & Liquidity-2 & & \\
\hline & Total & Total & Domestic & Foreign & Short-Term & M-to-L Term \\
\hline All & -0.0075 & -0.1006 & 0.0245 & 0.2183 & 0.3826 & 0.8894 \\
\hline Small & 0.0292 & 0.2111 & 0.3686 & 0.1776 & 0.6667 & 1.3449 \\
\hline Commercial & 0.0440 & 0.0432 & 0.3987 & 0.0424 & 0.3938 & 1.8507 \\
\hline Small-Commercial & 0.1318 & 0.8175 & 0.8171 & 0.0630 & 0.6728 & 2.2571 \\
\hline Foreign & & 1.6305 & 0.9208 & 2.9794 & & \\
\hline
\end{tabular}




\section{References}

Alper, C. Emre, M. Hakan Berüment, and N. Kamuran Malatyalı, 2001, “The Effect of the Disinflation Program on the Structure of the Turkish Banking Sector," Russian and East European Finance and Trade, vol. 37(6), pp. 81-95.

Arena, Marco, Francisco F. Vázquez, and Carmen Reinhart, 2007, “The Lending Channel in Emerging Economies: Are Foreign Banks Different?” IMF Working Paper 07/48.

Ashcraft, Adam B., 2006, “New Evidence on the Lending Channel”, Journal of Money, Credit and Banking, vol. 38(3), pp. 751-775.

Bank for International Settlements (BIS), 2006, “The Banking System in Emerging Economies: How Much Progress Has Been Made?” BIS Paper No. 28 (Basel, Switzerland, August).

Baum, Christopher F., Mustafa Çağlayan, and Neslihan Özkan, 2003, “Re-examining the Transmission of Monetary Policy: What More Do a Million Observations Have to Say,” Boston College Working Paper Series 561.

Berger, Allen N. and Christa H. S. Bouwman, 2008, “Bank Liquidity Creation,” Case Western Reserve University, Water School of Management, Research Paper.

Bernanke, Ben S. and Alan S. Blinder, 1988, “Credit, Money, and Aggregate Demand,” American Economic Review, vol. 78(2), pp. 435-439.

Bernanke, Ben S. and Mark Gertler, 1995, "Inside the Black Box: The Credit Channel of Monetary Policy Transmission,” Journal of Economic Perspectives, vol. 9, pp. 27-48.

Brooks, Petya Koeva, 2007, “The Bank Lending Channel of Monetary Transmission: Does it Work in Turkey?” IMF Working Paper No. 07/272.

Caprio, Gerard and Daniela Klingebiel, 1999, "Episodes of Systematic and Borderline Financial Crises,” unpublished manuscript, World Bank, Washington, D.C.

Degirmen, Suleyman, 2007, “Crowding Out, Interest and Exchange Rate Shocks, and Bank Lending: Evidence from Turkey,” International Research Journal of Finance and Economics, vol. 10, pp.76-87.

Denizer, Cevdet, 1999, “Foreign Entry in Turkey's Banking Sector, 1980-97,” World Bank Policy Research Working Paper No. 2462.

Deutsche Bank Research, 2005, “Turkey 2020: On Course for Convergence,” Deutsche Bank Research Publications, Current Issues.

Driscoll, John C., 2003, “Does Bank Lending Affect Output? Evidence from the U.S. States,” FEDS Working Paper No. 2003-31. 
Freixas, Xavier, 2005, “Deconstructing Relationship Banking,” Investigaciones Económicas, vol. 29(1), pp. 3-31.

Hauner, David, 2008, “Credit to Government and Banking Sector Performance,” Journal of Banking and Finance, vol. 32(8), pp. 1499-1507.

International Monetary Fund, 2007, “Turkey: Financial System Stability Assessment,” IMF Country Report No. 07/361.

International Monetary Fund, 2007, “The Globalization of Financial Institutions and its Implication for Financial Stability,” Global Financial Stability Report (Washington, DC, April).

Kashyap, Anil K. and Jeremy C. Stein, 2000, "What Do a Million Observations on Banks Say about the Transmission of Monetary Policy?” American Economic Review, vol. 90(3), pp. 407-428.

Kibritçioğlu, Aykut, 2005, "Banking Sector Crises and Related New Regulations in Turkey,” Macroeconomics 0505006, EconWPA.

Kishan, Ruby P. and Timothy P. Opiela, 2000, "Bank Size, Bank Capital, and the Bank Lending Channel,” Journal of Money, Credit and Banking, vol. 32(1), pp. 121-141.

McHale, John, 2001, “Turkey” in NBER Program on Exchange Rate Crises in Emerging Markets, available at www.nber.org/crisis/turkey_report.html

Şengönül, Ahmet and Willem Thorbecke, 2005, “The Effect of Monetary Policy on Bank Lending in Turkey,” Applied Financial Economics, vol. 15(13), pp. 931-934.

Soledad Martinez Peria, Maria and Beck Thorsten, 2008, “Foreign Bank Acquisitions and Outreach: Evidence from Mexico,” World Bank Policy Research Working Paper No. 4467. 